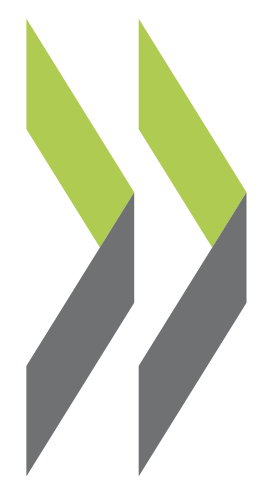

OECD Economics Department Working Papers No. 1239

\title{
Luxembourg - addressing new challenges in a major financial sector
}

Eckhard Wurzel,

Damien Azzopardi 
Organisation de Coopération et de Développement Économiques

Organisation for Economic Co-operation and Development

24-Jun-2015

ECONOMICS DEPARTMENT

English - Or. English

\section{LUXEMBOURG - ADDRESSING NEW CHALLENGES IN A MAJOR FINANCIAL SECTOR}

ECONOMICS DEPARTMENT WORKING PAPERS No. 1239

By Eckhard Wurzel and Damien Azzopardi

OECD Working Papers should not be reported as representing the official views of the OECD or of its member countries. The opinions expressed and arguments employed are those of the author(s).

Authorised for publication by Robert Ford, Deputy Director, Country Studies Branch, Economics Department.

All Economics Department Working Papers are available at www.oecd.org/eco/workingpapers

JT03379375

Complete document available on OLIS in its original format

This document and any map included herein are without prejudice to the status of or sovereignty over any territory, to the delimitation of

international frontiers and boundaries and to the name of any territory, city or area. 
OECD Working Papers should not be reported as representing the official views of the OECD or of its member countries. The opinions expressed and arguments employed are those of the author(s).

Working Papers describe preliminary results or research in progress by the author(s) and are published to stimulate discussion on a broad range of issues on which the OECD works.

Comments on Working Papers are welcomed, and may be sent to the Economics Department, OECD, 2 rue André-Pascal, 75775 Paris Cedex 16, France, or by e-mail to eco.contact@oecd.org.

The statistical data for Israel are supplied by and under the responsibility of the relevant Israeli authorities. The use of such data by the OECD is without prejudice to the status of the Golan Heights, East Jerusalem and Israeli settlements in the West Bank under the terms of international law.

\section{(C) OECD (2015)}

You can copy, download or print OECD content for your own use, and you can include excerpts from OECD publications, databases and multimedia products in your own documents, presentations, blogs, websites and teaching materials, provided that suitable acknowledgment of OECD as source and copyright owner is given. All requests for commercial use and translation rights should be submitted to rights@oecd.org 


\section{ABSTRACT/RÉSUMÉ}

\section{Luxembourg - Addressing New Challenges in a Major Financial Sector}

Over the last two and a half decades, Luxembourg's financial sector emerged as a leading international hub for asset management and investment funds and became a key contributor to growth. Diversification into new areas of financial asset management is continuing. However, changing financial market regulation in Europe, increased international transparency requirements for banking and heightened international competition pose challenges. Moreover, the financial sector has reached a size where its contribution to the economy's overall growth might diminish.

Maintaining sound framework conditions is important for further diversification in the financial sector, building on Luxembourg's existing comparative advantage and investors' trust in its economic stability. Regulators should ensure financial intermediaries maintain strong capital ratios to address potential financial market shocks from abroad and real estate risks in the domestic economy. Assessment of systemic risks should be based on a framework that accounts for the various linkages between the banks and the other relevant financial market actors, notably investment funds. Given that the bulk of the banks in Luxembourg are affiliates of foreign bank groups, the authorities should seek clear procedures that govern the (cross-border) resolution of large banks in bad times. Moreover, implementation of the remaining steps in upgrading the tax transparency regulations Luxembourg has committed to can increase incentives for banks to further refine their business models, benefitting Luxembourg's financial sector in the medium term.

This Working Paper relates to the 2015 OECD Economic Survey of Luxembourg (www.oecd.org/eco/surveys/economic-survey-luxembourg.htm).

JEL classification: G15, G18, G21, G22, G23, G28, H24, H25

Keywords: banks, financial markets, financial regulation, investment funds, insurance, risks, taxation

\section{Luxembourg - adresser des nouveaux défis d'un majeur secteur financier}

Pendant les vingt-cinq dernières années, le secteur financier luxembourgeois est devenu une plateforme internationale de premier plan pour la gestion d'actifs et les fonds de placement, ce qui a grandement contribué à la croissance. La diversification dans de nouveaux domaines de la gestion d'actifs financiers se poursuit. Toutefois, l'évolution de la réglementation des marchés financiers en Europe, les obligations accrues de transparence internationale en matière bancaire et l'intensification de la concurrence constituent des défis. En outre, le secteur financier a atteint une dimension telle que sa contribution à la croissance globale de l'économie risque de s'amenuiser.

Le maintien d'un cadre sain conditionne la poursuite de la diversification du secteur financier, à partir de l'avantage comparatif actuel du Luxembourg et de la confiance des investisseurs en sa stabilité économique. Les régulateurs doivent veiller à ce que les intermédiaires financiers aient des ratios de fonds propres élevés pour qu'ils puissent faire face à l'éventualité de chocs d'origine étrangère et aux risques liés au secteur immobilier national. L'évaluation des risques systémiques doit prendre en compte les divers liens qui existent entre les banques et les autres acteurs des marchés financiers, notamment les fonds de placement. La plupart des banques opérant au Luxembourg étant liées à des groupes étrangers, il incombe aux autorités de chercher à établir des procédures claires pour organiser la résolution (transfrontalière) de grandes banques en période de crise. En outre, l'application des dernières mesures d'amélioration de la transparence fiscale auxquelles le Luxembourg s'est engagé peut inciter les banques à affiner encore leurs modèles économiques, ce qui favorisera à moyen terme le secteur financier luxembourgeois.

Ce Document de travail se rapporte à l'Étude économique de l'OCDE de Luxembourg, 2015 (www.oecd.org/fr/eco/etudes/etude-economique-luxembourg.htm).

Classification JEL: G15, G18, G21, G22, G23, G28, H24, H25

Mots clefs: les banques, les marchés financiers, la règlementation financière, les fonds d'investissements, l'assurance, les risques, la taxation 


\section{TABLE OF CONTENTS}

\section{LUXEMBOURG: ADDRESSING NEW CHALLENGES IN A MAJOR FINANCIAL SECTOR ...............5}

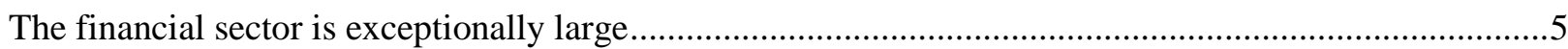

Most banks are affiliates of international bank groups with cross-border business models ...................6

Credit to domestic borrowers has held up and banks remain resilient .................................................

The financial sector has diversified into asset management and insurance ..........................................12

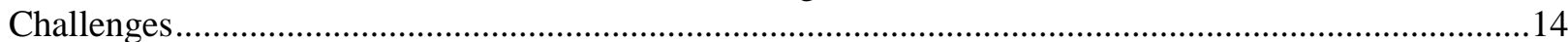

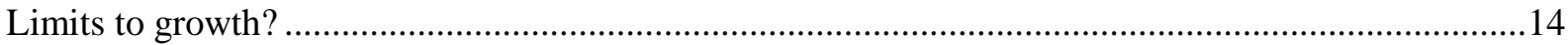

Increased volatility of tax revenues from financial sector activities? ..............................................16

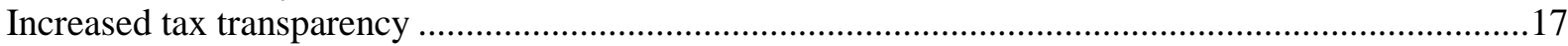

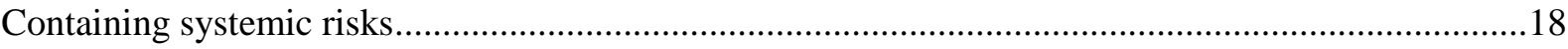

ANNEX MEASURING OUTPUT AND PRODUCTIVITY IN THE FINANCIAL SECTOR ..................22

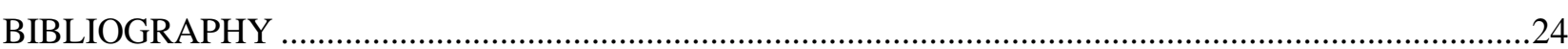

\section{Tables}

1. Capital adequacy requirements for banks in Luxembourg ............................................................20

\section{Figures}

1. Assets of monetary and financial institutes (MFIs excluding the Eurosystem) ..............................6

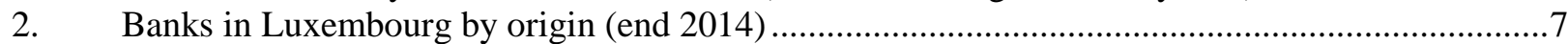

3. Funding interconnections between credit institutions and financial and non-financial sectors .......8

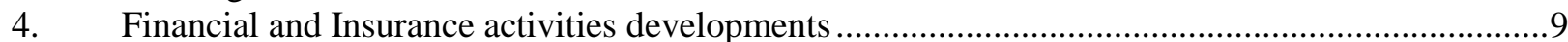

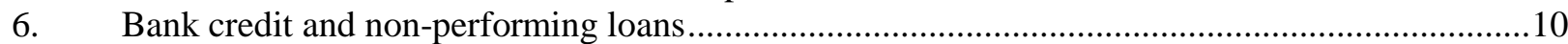

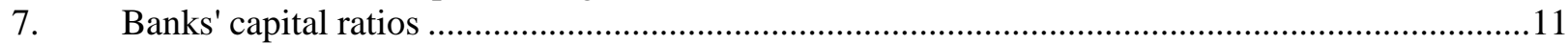

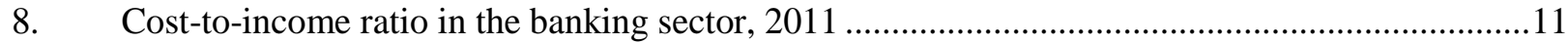

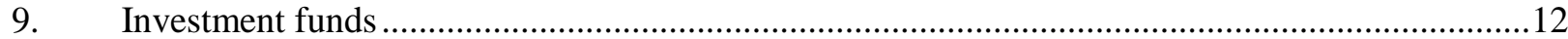

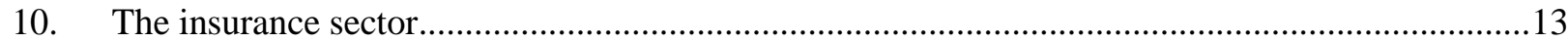

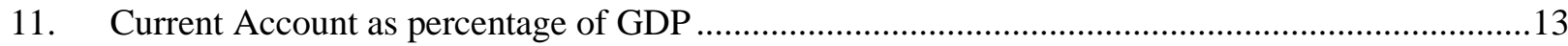

12. International comparison of GVC participation index for selected industries, 2009 ...................15

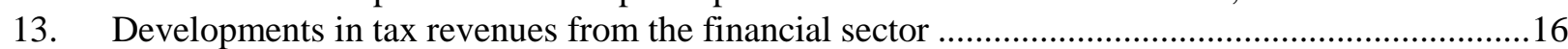

14. Deposits held by credit institutions in Luxembourg ................................................................18

15. Credit granted by credit institutions for real estate located in Luxembourg .................................21

16. Branches and subsidiaries in Luxembourg of foreign credit institutions ......................................21

\section{Boxes}

Box 1. Luxembourg's response to the recommendations by the Global Forum on Transparency and Exchange of Information for Tax Purposes

Box 2. Macroprudential measures taken by the CSSF and the BCL .................................................20 


\section{LUXEMBOURG: ADDRESSING NEW CHALLENGES IN A MAJOR FINANCIAL SECTOR}

\section{By Eckhard Wurzel and Damien Azzopardi ${ }^{1}$}

Over the last two and a half decades, Luxembourg's financial sector has emerged as a key contributor to economic activity. Luxembourg's comparative advantage as an international financial hub has been aided by an adaptive legislative and regulatory framework that took advantage of early adoption of EU financial regulation, low taxation, a skilled workforce and accumulation of specialised knowledge in asset management. However, more recently, the sector's share in total output has declined and the sector might have reached a size where its contribution to the economy's overall growth might be diminishing. This paper addresses policy challenges to safeguard the ability of the financial sector to adjust in a new and changing international regulatory framework.

\section{The financial sector is exceptionally large}

The value added share of the financial and insurance sector in Luxembourg was about $27 \%$ of GDP in 2014, well above other OECD main financial centres such as Switzerland (10 $1 / 2$ per cent) or the United Kingdom ( $81 / 4$ per cent). Banks accounted for $20 \%$ of total financial sector value-added in 2013 with the remainder from various asset management and investment fund activities. Relative to the country's GDP, total assets of the monetary and financial institutes (MFIs, credit institutes and money market funds) are exceptionally large by international comparison, although in absolute terms the size is much more modest (Figure 1). Measuring output and productivity in the financial sector is subject to a considerable degree of uncertainty, with output possibly overstated (Annex 1).

The sector has diversified substantially over the years, and diversification in new areas is ongoing. Financial market activities related to banking that have gained in importance in recent years include bond issuance, custody services for investment funds, personal wealth management for high income families and IT-related financial services (OECD, 2012; Wintersteller, 2013). Luxembourg plays an important role as a hub for euro-denominated bond issuance, hosting one of the major clearing and settlement agencies. The country is also a global hub for investment funds (see below). In addition, the financial sector has important linkages to various support activities such as legal services and IT.

\footnotetext{
${ }^{1}$ Eckhard Wurzel was head of the Luxembourg Desk in the Economics Department of the OECD; Damien Azzopardi was a statistician on the Luxembourg Desk. This paper is based on Chapter 1 of the 2015 OECD Economic Survey of Luxembourg, published in March 2015 under the authority of the Economic and Development Review Committee (EDRC). Special thanks go to Peter van de Ven of the OECD's Statistics Directorate, who wrote the Annex on measuring output in the financial sector. The author would also like to thank Robert Ford, Alvaro Pereira, Piritta Sorsa and colleagues from the OECD's Centre for Tax Policy and Administration and the Directorate for Financial and Enterprise Affairs for valuable comments. Also, the report benefited from comments from the Luxembourg authorities. Anthony Bolton and Mikel Inarritu helped with excellent administrative assistance.
} 
Figure 1. Assets of monetary and financial institutes (MFIs excluding the Eurosystem)

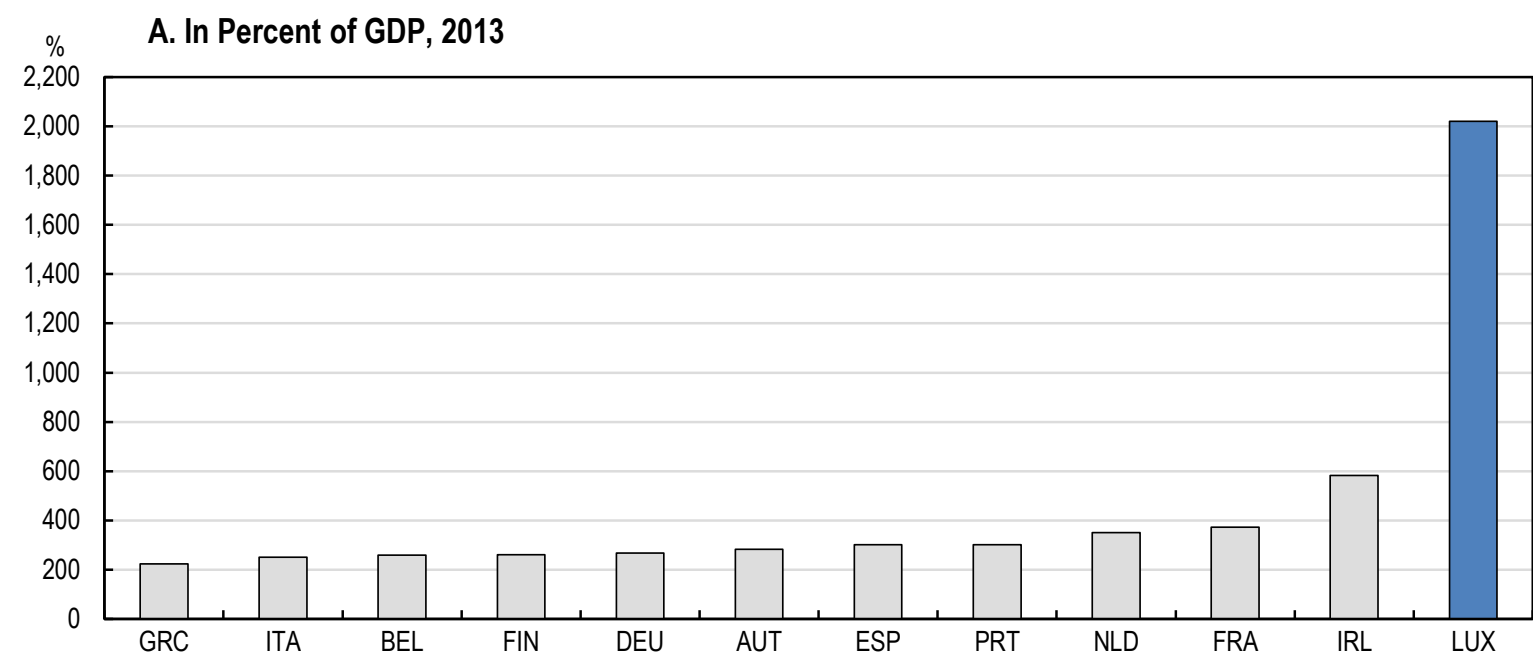

B. In EUR billion, 2013

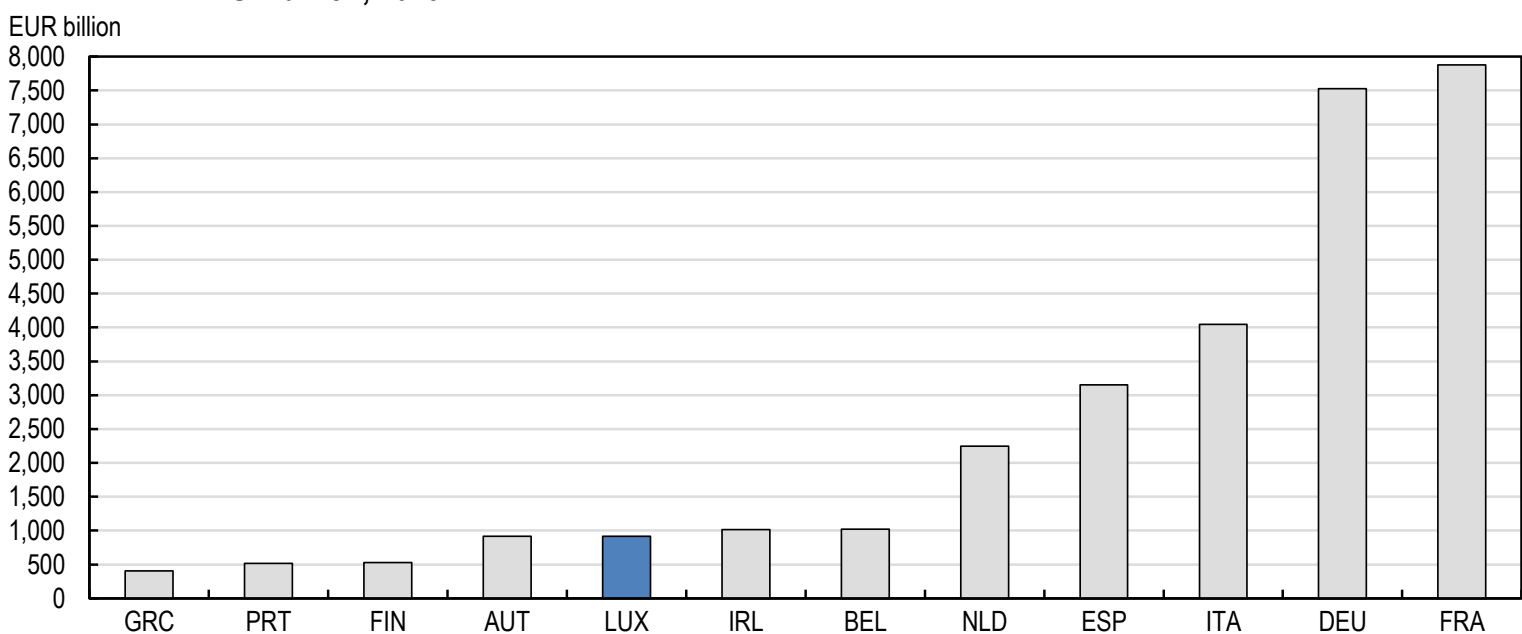

Source: European Central Bank.

\section{Most banks are affiliates of international bank groups with cross-border business models}

Only 5 banks in Luxembourg are of Luxembourgish origin, the rest being owned by foreign credit institutions (Figure 2). Some $80 \%$ of the banks are of European origin, but banks from the United States, Japan, China, Brazil and other non-European countries are also represented. Some $87 \%$ of total bank assets are located in banks belonging to foreign banking groups (last quarter 2013).

In the last semester 2013, foreign lenders accounted directly for some 54\% of the banks' financial obligations (Figure 3). Inter-bank funding within Luxembourg's banking system made up another $171 / 2$ per cent, and money-market and investment funds located in Luxembourg contributed 17\% (see below). 
Figure 2. Banks in Luxembourg by origin (end 2014)

Number, percentage in parenthesis.

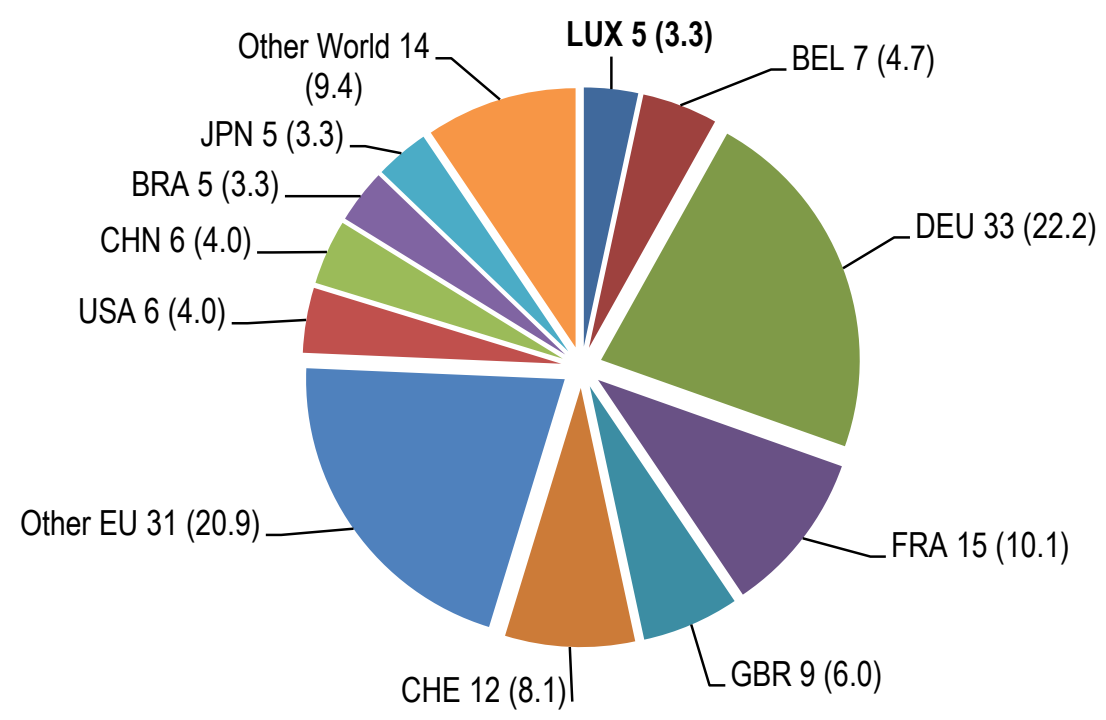

Source: CSSF.

Most banks are engaged in international business activities. A major part of the banks' business model is to act as cross-border hubs providing liquidity to their international bank groups. This is because Luxembourg's banks are strongly benefitting from deposits by investment funds, insurance companies and other financial intermediaries, which accounted for $81 \%$ of total bank deposits in 2014. In particular, the working balances of investment funds act as a relatively stable source of funding for the custodian banks. The custodian banks are liquidity rich as they have only limited credit activities vis-à-vis the non-financial sector. Indeed, at the end of 2013, about two third of Luxembourg's banks providing inter-bank credit allocated their funds exclusively to foreign banks. Those credits accounted for 58\% of overall Luxembourgish bank credit. Another $27 \%$ of total bank credit was allocated to non-bank foreign counterparties (Figure 3). Loans to enterprises and households in Luxembourg and the government account for a relatively small part of the total credit that the banks in Luxembourg are extending.

At the initial phase of the 2008 crisis, some bank subsidiaries had to raise liquidity for their foreign banking groups (IMF, 2011) by drawing on the ECB's liquidity facilities. This raised the banks' indebtedness vis-a-vis the Central Bank. However, liquidity shortages between banks remained subdued, given the relatively limited role of the domestic interbank market in channelling liquidity across banks (Figure 3). At the same time, Luxembourg's banks continued to act as a relatively stable provider of funding for foreign, mostly European, banks. 


\section{ECO/WKP(2015)57}

Figure 3. Funding interconnections between credit institutions and financial and non-financial sectors

A. The sectors' contributions to the funding of credit institutions Percentage of the banks' total obligations, 2013Q4

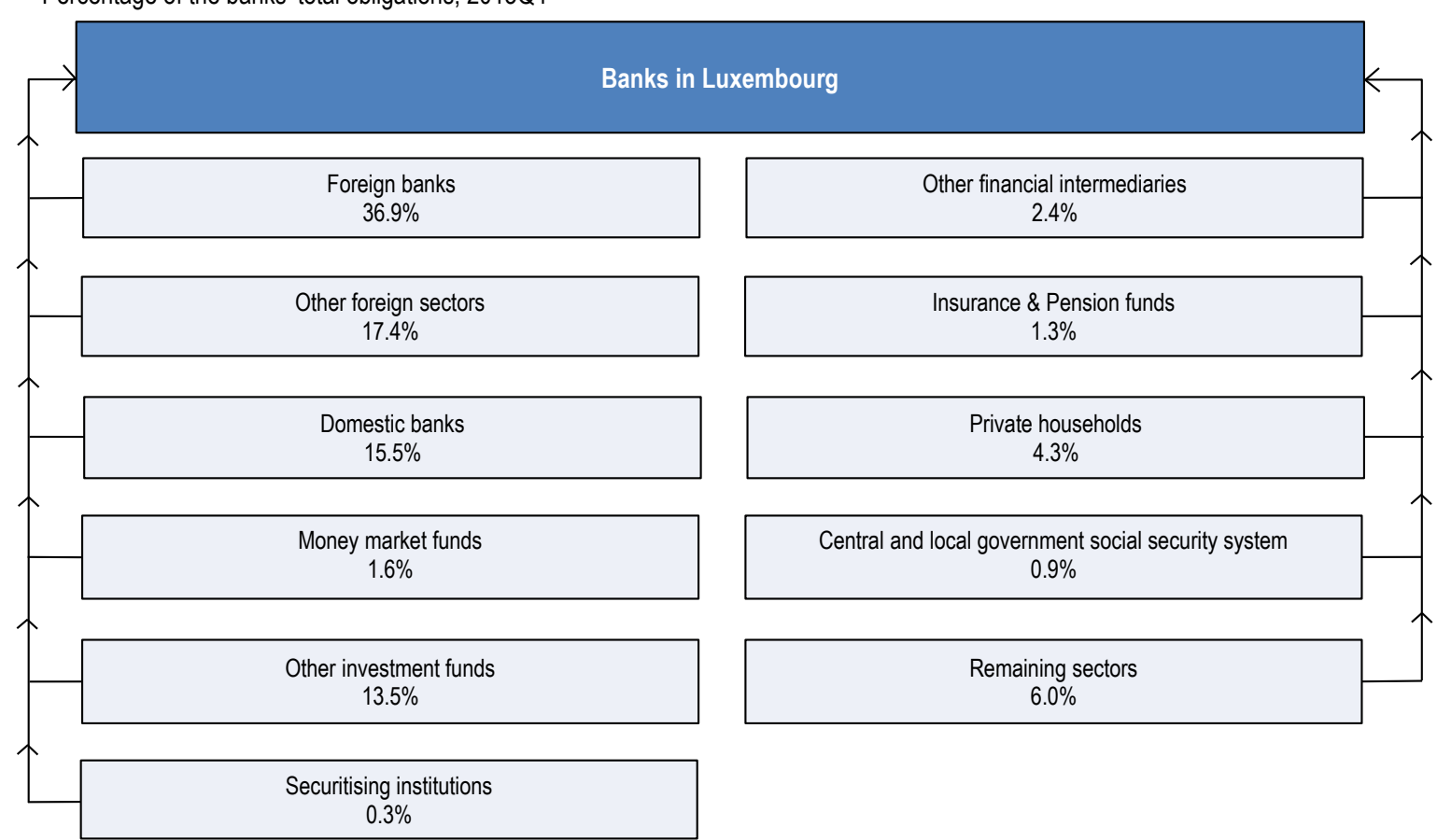

B. The credit institutions' contributions to the funding of the sectors Percentage of the banks' total claims, 2013Q4

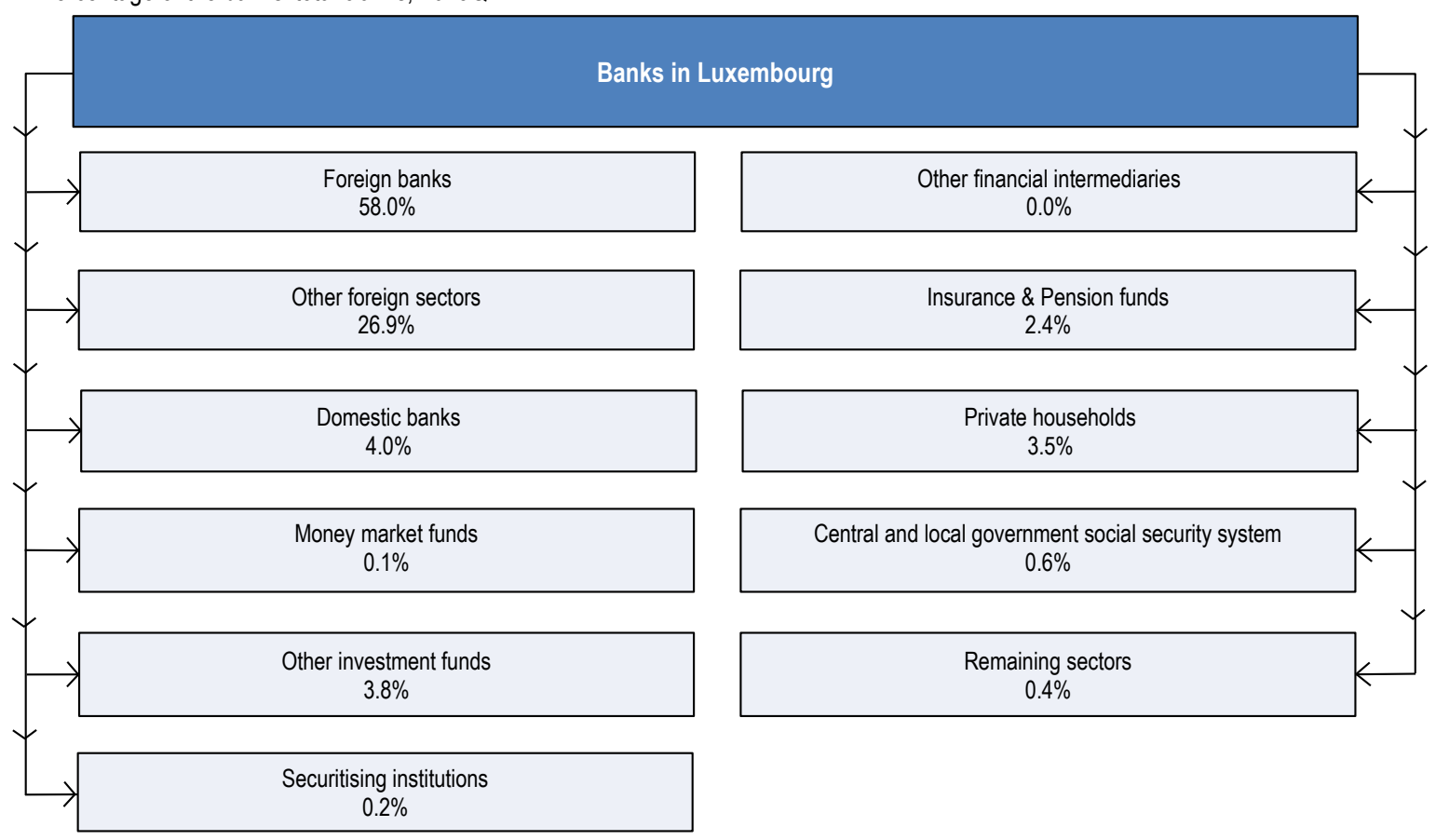

Source: Revue de stabilité financière 2014, BCL. 
Since the crisis the share of the financial and insurance sector in the economy's real value added dropped by some 4 percentage points (Figure 4, panel A) as banks' aggregate balance sheets contracted by $14 \%$ between 2008 and 2009. Markets for short term liquidity dried up, which led to downsizing of exposures to levels that are close to those at the beginning of the last decade. The bulk of adjustment in banks' lending occurred via reductions in cross-border credit by subsidiaries and branches to their group's foreign banks (Figure 4, panel B)

Figure 4. Financial sector developments
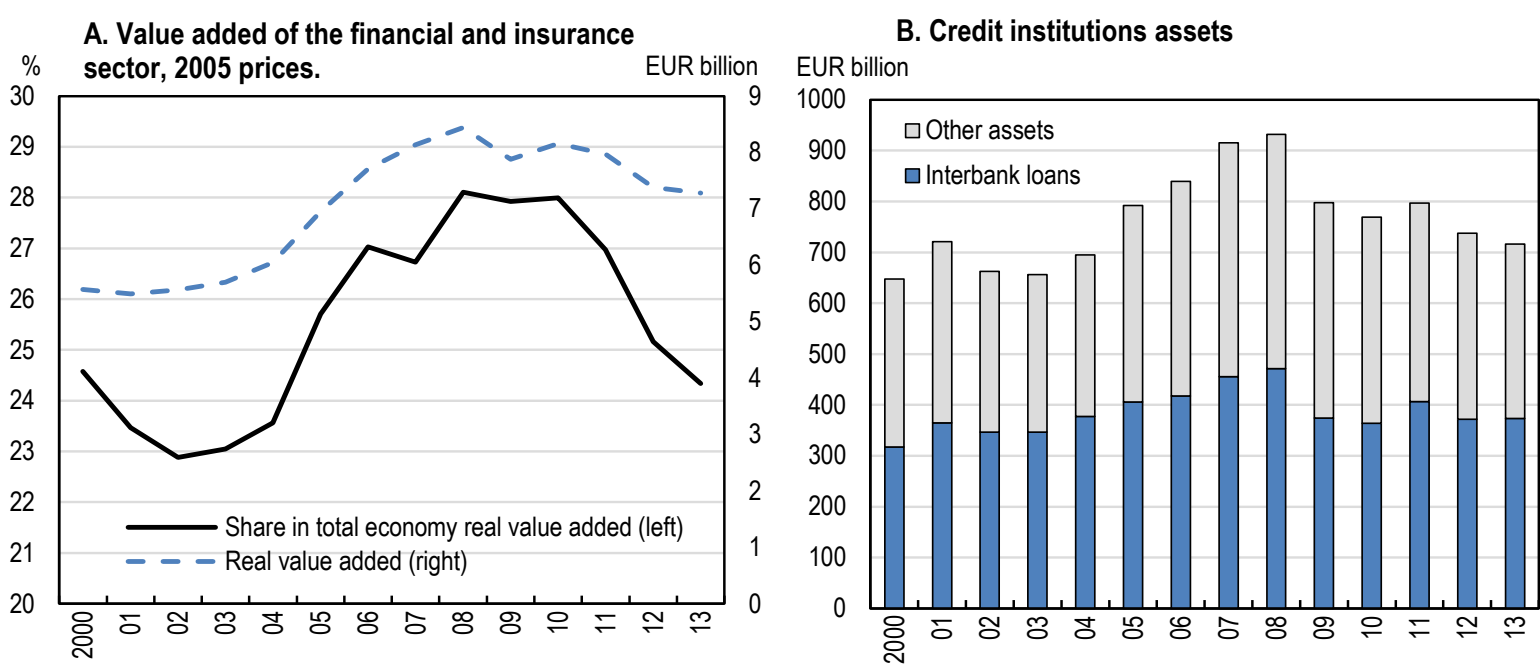

Source: STATEC; BCL.

\section{Credit to domestic borrowers has held up and banks remain resilient}

Credit to the domestic private non-financial sector, measured in terms of GDP, is below the OECD average (Figure 5), but was remarkably resilient since the crisis. Bank credit to non-financial enterprises continued to rise, with banks tightening credit conditions only marginally, in contrast to most other countries in the euro area (Figure 6, panel A).

Figure 5. Credit to the domestic private non-financial sector by banks in Luxembourg

As percentage of GDP, 2013

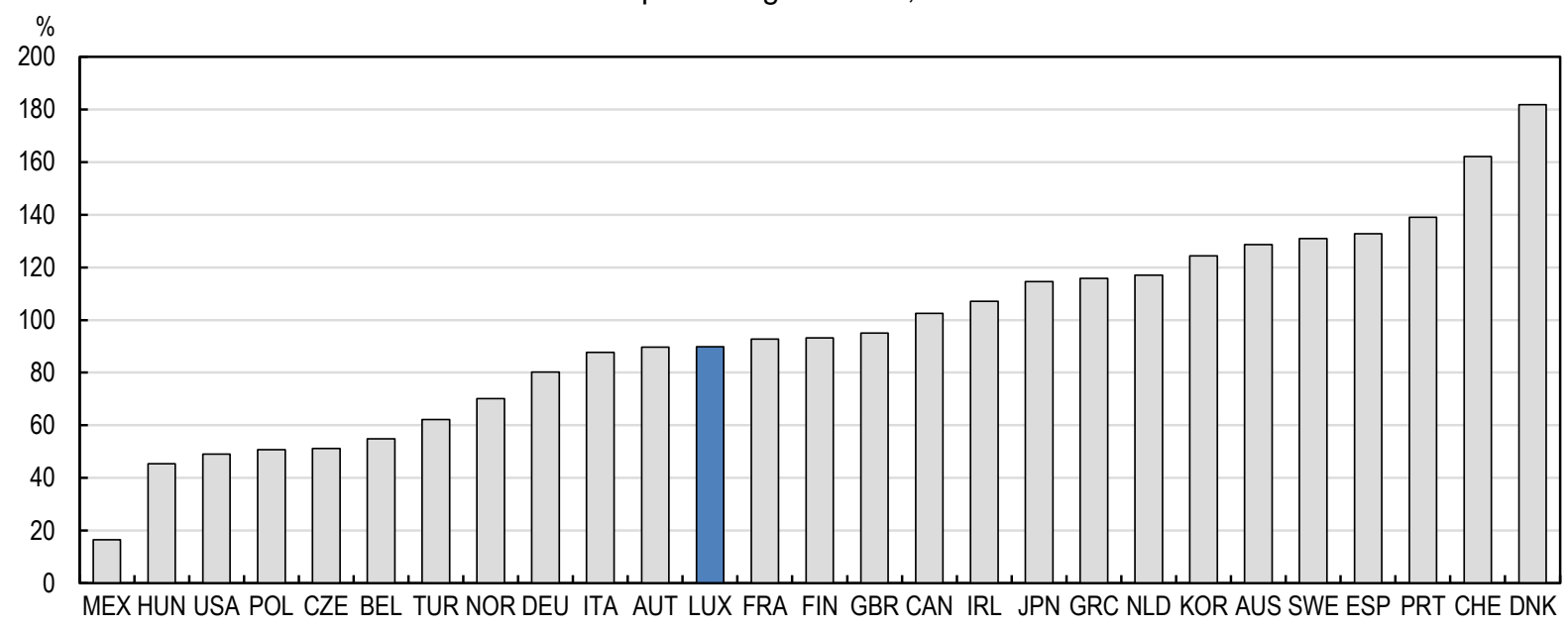

Source: BIS. 
Figure 6. Bank credit and non-performing loans
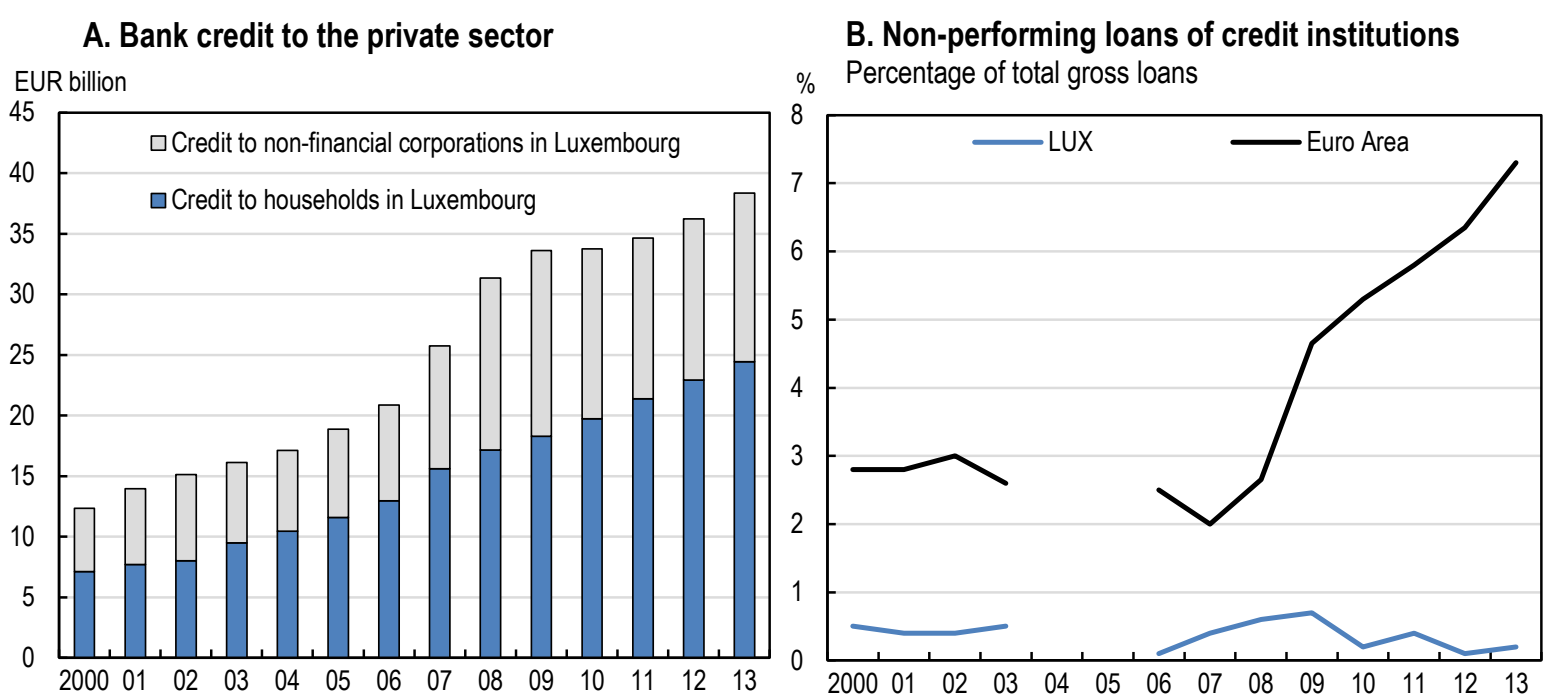

Source: BCL and World Bank, World Development Indicators Database.

A number of factors underpin the relatively high resilience of bank loans to the domestic private sector. Banks were well capitalised when the crisis commenced, and the supervisory authority was early in requiring banks to raise capitalisation towards future Basel III and European Union standards. In the "comprehensive balance sheet assessment" for systemically important banks by the European Central Bank, published in October 2014, no capital shortfall has been identified for the six assessed credit institutes in Luxembourg (European Central Bank, 2014a). The banks passed the reference capitalisation thresholds both for the "asset quality review" and for the two conducted "stress tests". The banks' assets were found to be appropriately valued. Also, the solvency ratios remained significantly above the required threshold set in the stress test.

Capitalisation of the banking system overall also appears to be relatively high, based on the ratio of regulatory capital to risk weighted assets (Figure 7). Non-performing loans account for only a small portion of total bank credit, reflecting healthy balance sheets and a well-diversified loan portfolio prior to the crisis, past bank restructuring and economic growth above the EU average in recent years (Figure 6, panel B). The banks' cost to income ratio is relatively low by international comparison, indicating a relatively high degree of technical efficiency (Figure 8).

Moreover, the financial safety net coped well with a number of insolvencies in the initial phase of the crisis, which originated abroad and spilled into subsidiaries in Luxembourg via cross-border funding linkages. In a few cases, the deposit insurance had to step in when international banks with subsidiaries in Luxembourg needed to be restructured (CSSF, 2011). The restructuring also involved financial aid by the government. 
Figure 7. Banks' capital ratios
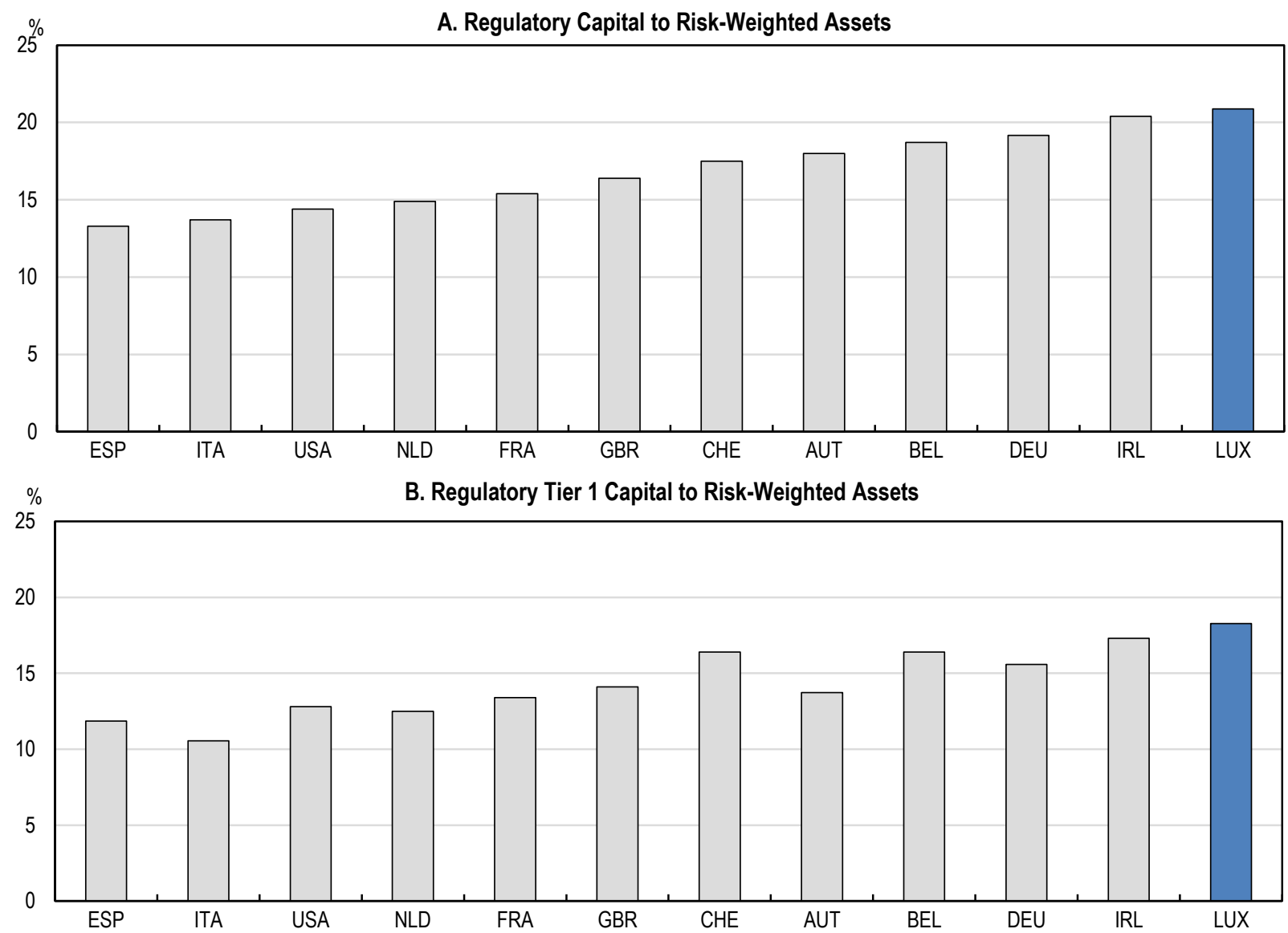

Note: Based on quarterly data as of December 2013; where these are not available the most recent available data are taken, extending back to December 2012.

Source: IMF Financial Soundness Indicators report, data submitted by national authorities to the IMF for dissemination through FSIs website http://fsi.imf.org/, data submitted to the IMF Area Department, and IMF staff estimates.

Figure 8. Cost-to-income ratio in the banking sector, 2011

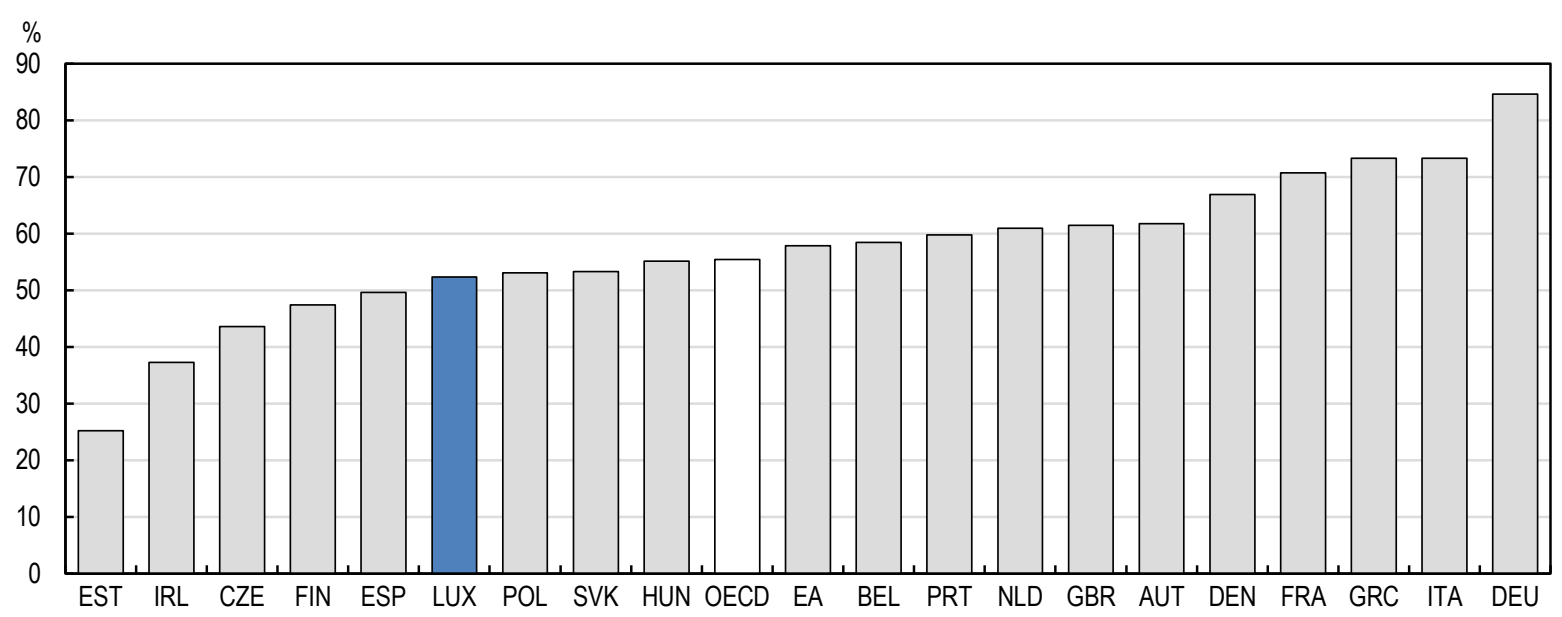

Source: World bank, Global Financial Development indicators, November 2013 version. 


\section{The financial sector has diversified into asset management and insurance}

Luxembourg's funds sector benefitted from early adoption in the mid-1980s of the EU directive on Undertakings for Collective Investment in Transferable Securities (UCITS), which provided the regulation for UCITS investment funds to operate freely throughout the EU on the basis of a single authorisation. Since then, Luxembourg has developed as a hub for the administration and distribution of investment funds, with about 4000 investment funds located in the country at the end of 2014 (Figure 9). By end-2014, the funds had EUR 3.5 trillion net assets under management, more than twice the figure at trough of the financial crisis. Luxembourg is now the world's second largest investment fund centre after the United States. Non-UCITS investment funds have also grown, with Luxembourg having been one of the first countries to adopt the EU's directive on Alternative Investment Funds at the beginning of the decade.

Figure 9. Investment funds
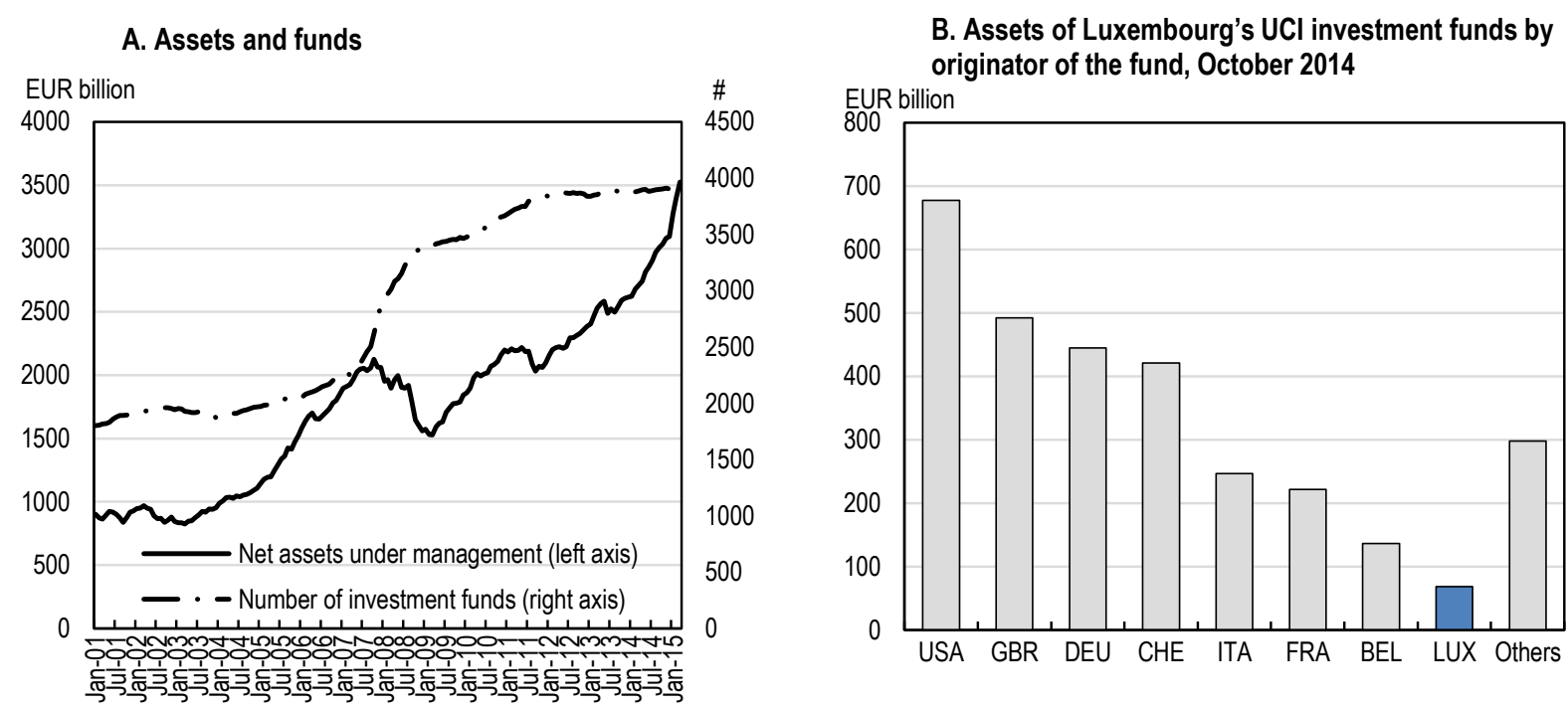

Note: Undertakings for collective investment (UCI).

Source: Commission de Surveillance du Secteur Financier, Luxembourg.

Benefitting from Luxembourg's financial infrastructure, the insurance sector has also recorded strong growth, driven by rapid expansion of life insurance, which accounts for almost $60 \%$ of insurance products, and (to a lesser extent) re-insurance (Figure 10). 95\% of the risks insured by Luxembourg's insurers are outside Luxembourg.

Investment funds were also hit by the crisis. Total assets under management declined by $24 \%$ in 2008 on account of falling asset prices and subdued investors demand, but recovered quickly to resume buoyant growth (Figure 9 above). Overall, diversification within the financial sector has contributed to limiting the contraction of financial sector output and helped employment in the financial sector to recover after a decline during the first years of the crisis. 
Figure 10. The insurance sector

A. Insurance premia, 1998-2013

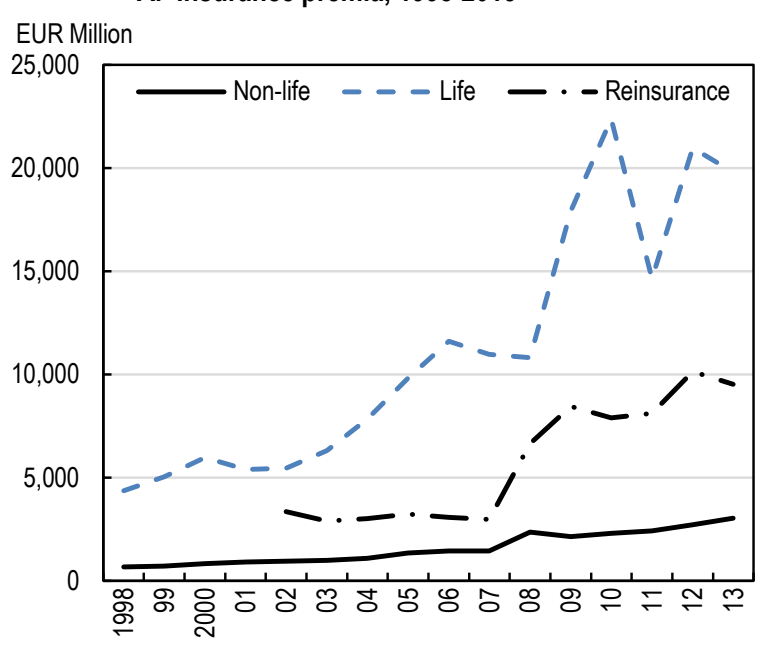

B. Insurance premia paid by type and origin, 2013

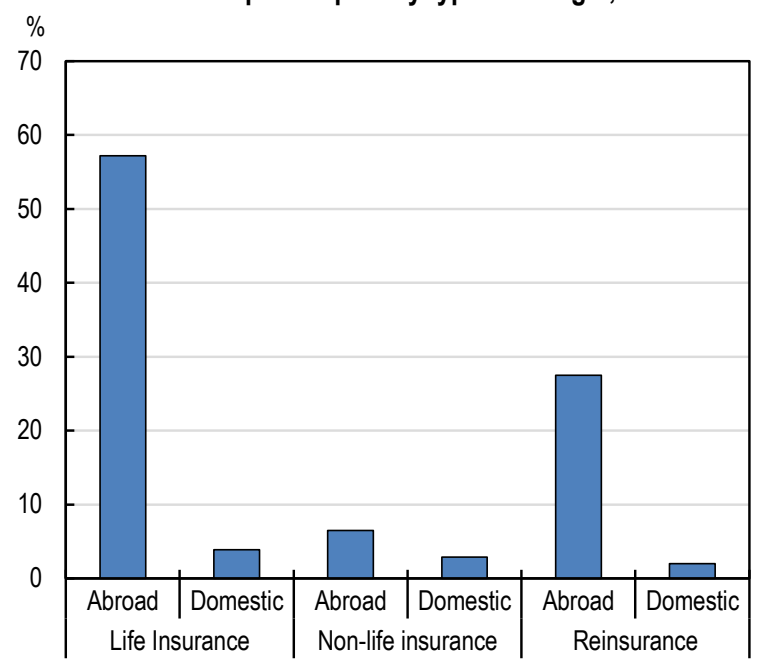

Source: Commissariat aux Assurances, Luxembourg.

The strong competitive position of the financial and insurance sector is reflected in the sector's strong export performance. Eighty per cent of the output of the financial and insurance sector is exported. Financial services account for about $50 \%$ of total exports, as compared to some $11 \%$ in the United Kingdom and 5.5\% in Switzerland and $4.2 \%$ in the United States. The economy has long run a large current account surplus (some 5\% of GDP in 2014), which is entirely attributable to services exports, with financial services accounting for their largest part (Figure 11). The share of financial sector output in the overall trade surplus has recently declined, however, reflecting both the adverse impact of the financial crisis and strengthening exports of other services, notably ICT services.

Figure 11. Current Account as percentage of GDP

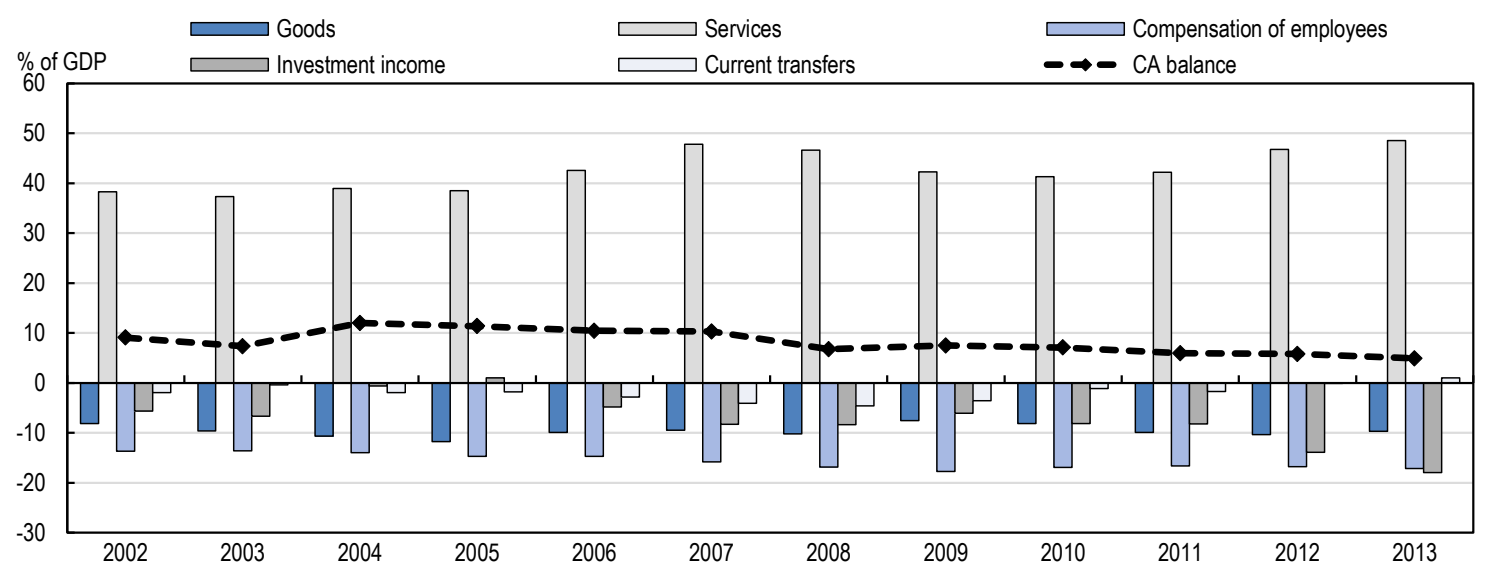

Source: STATEC. 


\section{Challenges}

For high-income economies like Luxembourg - within the OECD, Luxembourg's per-capita gross domestic product and gross national income are only surpassed by Norway - activities that produce high value-added should be particularly important going forward, as they are relatively highly remunerated. High value-added activities tend to be technology and knowledge intensive. Thus, they are also less contestable because required skills are more difficult to obtain. Moreover, given the small size of the domestic economy, Luxembourg will have to rely on high integration in global value-chains, which broadens effective market size (see also OECD, 2013). Luxembourg's integration of financial services (considered to be knowledge-intensive) in the global value added chains (GVC) is the highest in the OECD (Figure 12). Since the middle of the 1980s Luxembourg's economy has strongly benefitted from the upswing in the demand for financial services in industrialised countries, which interacted with the firstmover advantages from past financial sector liberalisation and at times early adoption of EU financial services directives. Luxembourg's scores on the OECD's Services Trade Restrictiveness Indicators are below (meaning more open for international trade) the OECD average in commercial banking, insurance and almost all other service sector activities.

However, cross-border demand for intermediated credit might be less vigorous going forward than it was in past decades. Emerging financial centres elsewhere, notably in China and South America, are increasing competitive pressure. Luxembourg's financial sector needs to rely on maintaining a highly qualified workforce and stability-oriented framework conditions to stay competitive. Changing financial market regulation in Europe and the drive for more transparency can pose challenges for banks to adjust.

\section{Limits to growth?}

Time series analysis by Guarda and Rouabah (2011) suggests that growth innovations in Luxembourg's financial sector are leading those in other sectors. However, several recent econometric studies have found a hump-shaped relationship between the size of an economy's financial sector and economic growth (Arcand et al, 2012; Cecchetti et al, 2012; Beck, et al, 2014; Law et al, 2014; Cournède et al. 2015, Cournède and Denk 2015; see also European Systemic Risk Board, 2014). A larger financial sector is linked to higher aggregate economic growth at lower levels of financial development, but further expansion of an already large financial sector can be associated with slowing GDP growth.

Generally, limits to growth contribution can reflect a number of factors: resource misallocation due to rent seeking and implicit government guarantees; exposure to financial shocks and increases in growth raising income inequality. Based on these estimates, intermediated credit in Luxembourg might have reached a size where its growth contribution diminishes. To some extent, implicit (or explicit with banks owned by the public sector) bank guarantees might have encouraged risk-taking of banks and their customers in Europe and Luxembourg, expanding the size of the banking sector at the expense of other activity. Estimates suggest that one of the banks that had to be resolved during the financial crisis was enjoying a significant implicit debt guarantee (Schich and Lindh, 2012). However, the work by Cournède and Denk (2015) suggests that a potentially adverse effect associated with size is less relevant for international financial centres, such as Luxembourg, that export a large share of financial sector output.

Nonetheless, if further financial sector expansion fails to be beneficial for economic growth in many countries, international demand for financial sector services could slow. Moreover, tightening capital requirements for banks in Europe and elsewhere and more effective risk control in the EU Banking Union (see below) might put deleveraging pressures on banks, possibly reducing the size of international bank groups and their affiliates in Luxembourg. These contingencies support the case in favour of improving framework conditions that foster the diversification of economic activity across the economy overall. 
Figure 12. International comparison of GVC participation index for selected industries, 2009
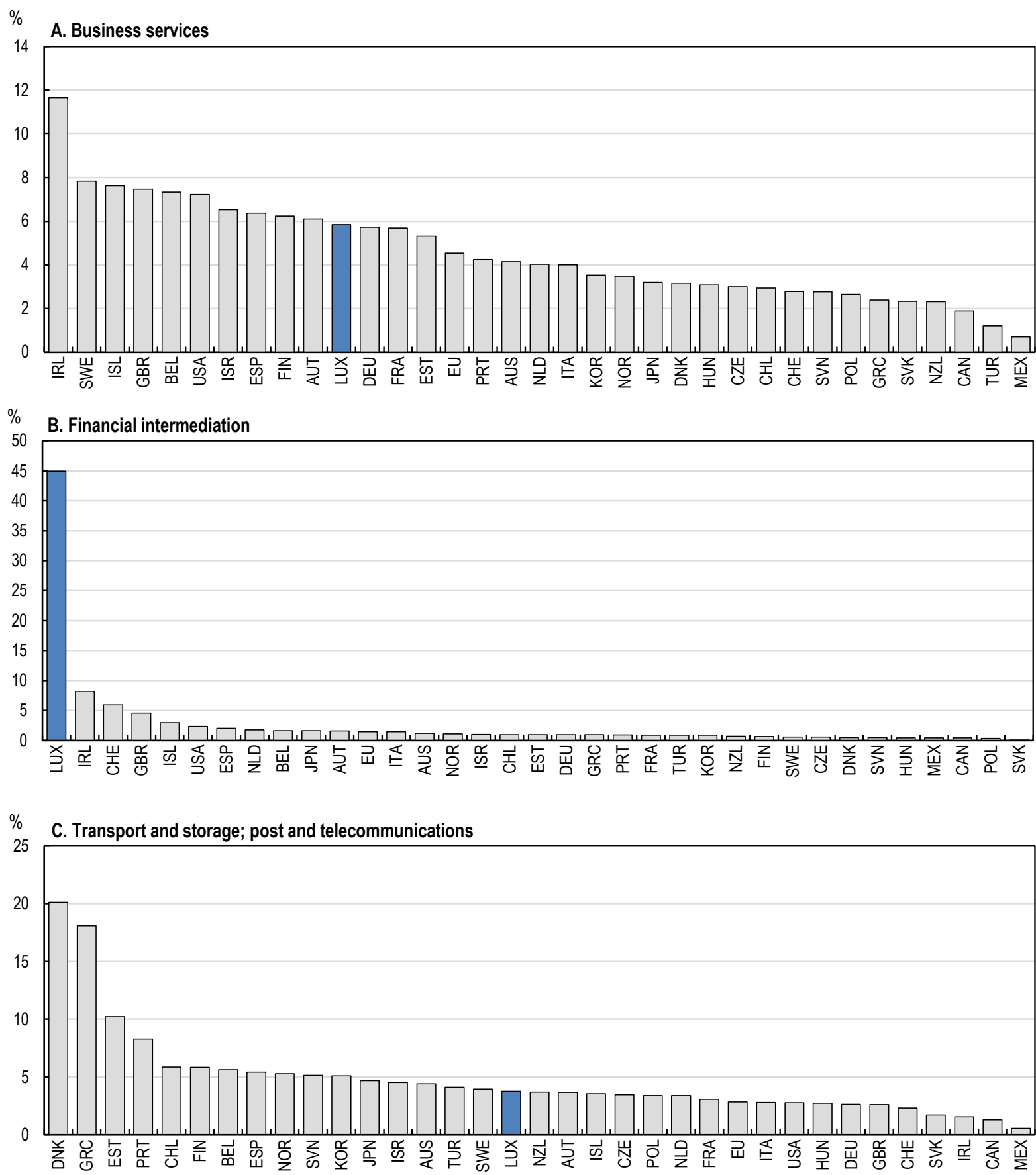

Note: The participation index is calculated as the sum of: (i) the share of foreign inputs in overall exports, and (ii) the share of gross exports that are used as inputs in other countries' exports.

Source: OECD Global Value Chains indicators. 


\section{Increased volatility of tax revenues from financial sector activities?}

OECD Economic Surveys on Luxembourg have pointed to a link between the volatility of government revenues in Luxembourg and the volatility of tax returns from the financial sector (OECD, 2012). In particular, taxes on bank profits have turned out to be quite volatile (Figure 13, panel A). The diversification in the financial sector has also diversified the tax base and might have reduced the volatility of tax revenues. The share of bank profit taxes in total tax receipts has declined while the share of insurance profit taxes and of the subscription tax, a tax on corporate securities (essentially on mutual funds), have risen (Figure 13, panel B). Ongoing financial sector output diversification could further reduce the positive correlation between financial sector tax returns and thus overall tax volatility. However, any major turmoil in financial markets could bring back revenue volatility, thus reinforcing the need to diversify the tax bases.

Figure 13. Developments in tax revenues from the financial sector
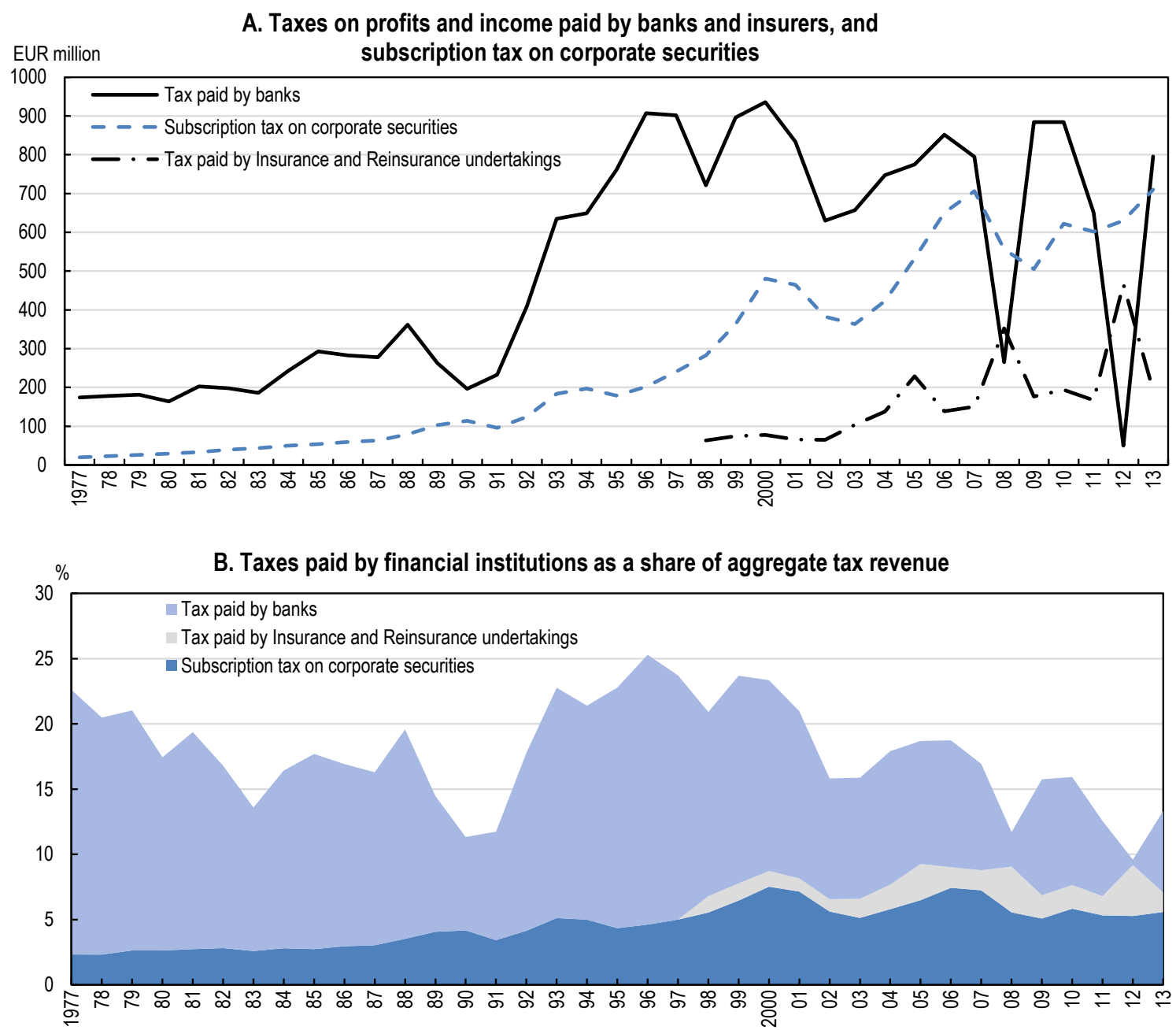

Source: STATEC, BCL and CAA. 


\section{Increased tax transparency}

The 2013 Phase-2 review of the Global Forum on Transparency and Exchange of Information for Tax Purposes showed that Luxembourg's tax relevant information practices during the review period were not fully in line with the standard on exchange of information on request. The legal and regulatory framework provides for the availability of ownership, accounting and bank information, and Luxembourg exchanges a considerable amount of information in a timely manner. However, information gathering and enforcement powers to obtain requested information have not been used in all instances. To improve its rating by the Global Forum, Luxembourg has reported that it has acted on all of the recommendations made in its report by the Global Forum (see Box 1). A supplementary review process has been launched at the beginning of January 2015, to evaluate the changes made and a supplementary report is expected to be published by the Global Forum by the end of July 2015. Also, Luxembourg has committed to implement the new automatic exchange of information standard by 2017 and signed the Multilateral Competent Authority Agreement with 51 other jurisdictions.

\section{Box 1. Luxembourg's response to the recommendations by the Global Forum on Transparency and Exchange of Information for Tax Purposes}

Luxembourg has reported that it has acted on all of the recommendations made in the country report for Luxembourg of the Global Forum on Transparency and Exchange of Information (EOI) for Tax Purposes. This includes:

- Luxembourg has signed and ratified the Multilateral Joint Council of Europe/OECD Convention on mutual administrative assistance in tax matters and its Protocol, hence enlarging its EOI network to all 83 parties to this Convention. The Convention entered into force on 1 November 2014. To date Luxembourg has an EOI relationship with 105 jurisdictions of which 97 are to the standard.

- In August 2014, a law immobilising all bearer shares entered into force ensuring that information relating to bearer securities holders will be available in any circumstance. Regarding the ownership information relating to SICARs taking the form of a Secs, a law of 12 July 2013 assures that SICARS taking the form of a Secs will be subject to the common registration and publication obligations provided for by commercial law.

- As of 1 January 2014 a circular of the Director of the direct tax administration concerning the procedure for the exchange of information on request came into force which clarifies the procedure and inter alia addresses the issues relating to the interpretation of the foreseeably relevance and to the exercise of compulsory powers by the competent authority.

- The law of 25 November 2014 modifying the procedure applicable for exchange of information on request, applicable since 1 December 2014, clearly states that the competent authority can compel communication of any documents or information sought by the requesting jurisdiction. It forbids alteration of the requested information by the information holder and abolishes the right to appeal of the information holder and the taxpayer against the request. Courts can no longer interpret the foreseeable relevance of requests.

Following these changes, Luxembourg has submitted a request to the Global Forum for launch of a supplementary report so that these changes can be evaluated. After a decision is taken regarding the launch by the Global Forum's Peer Review Group, a supplementary report is expected to be published by the end of July 2015 . This report will also determine whether any upgrades to its compliance ratings are warranted.

Following the government's announcement, in April 2013, to introduce an automated data exchange, bank deposits from non-financial counterparties remained stable (Figure 14). Reductions in deposits by non-financial and non-residential counterparties - notably private households in neighbouring countries were offset by increases in deposits by non-financial and residential counterparties. The remaining steps in upgrading the tax transparency regulations should be made soon. This would increase incentives for banks to further refine their business models, benefitting Luxembourg's financial sector in the medium term. 
Figure 14. Deposits held by credit institutions in Luxembourg

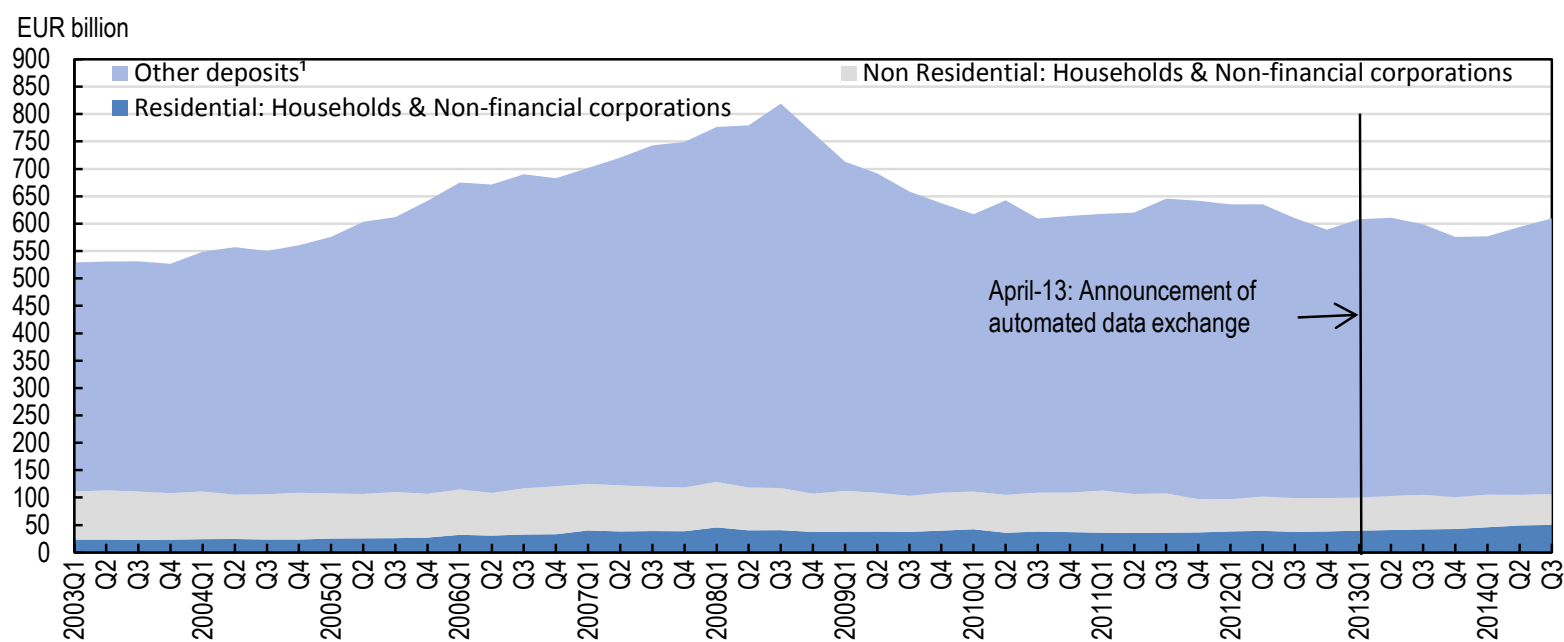

1. Categories in Other deposits: Credit institutions, General government, Other financial intermediaries \& Financial auxiliaries, Insurance corporations \& Pension funds.

Source: BCL.

\section{Containing systemic risks}

Securing stability in the financial sector is of utmost importance for Luxembourg's economic development. The crisis illustrated that shocks to the financial sector can have a profound impact on the economy, with Luxembourg's GDP having dropped steeply at the outset of the crisis, although the economy's subsequent recovery was quicker than in many other OECD economies, particularly in the euro area. An econometric study carried out in the early phase of the crisis concluded that a $1 \%$ decline in financial-sector real value added can be associated with a decline in GDP by $0.6 \%$ in the first year and another $0.3 \%$ in each of the following two years (STATEC, 2008).

More fundamentally, the diversification of the financial sector into new areas of activity, such as the investment fund industry, builds on investors' trust in stable framework conditions. Uncertainty about Luxembourg's capacity to keep systemic risk at the minimum could thus be very disruptive for further financial sector development, given the high mobility of international capital flows. Thus, strong bank capitalisation and a strong regulatory framework are required to validate investors' trust. It is therefore welcome that Luxembourg's authorities have introduced the fully phased-in Basel III solvency ratio as of 2014 and introduced a $2.5 \%$ capital conservation buffer for all banks as of 2014, making use of the discretion allowed by the relevant EU legislation. Draft laws providing for the full introduction of the countercyclical capital buffer and buffers for systemic banks and systemic risk are in the legislative process.

The prevalence in the banking sector of ownership and credit linkages across borders implies a certain degree of risk sharing with foreign banks if adverse events in Luxembourg's banking sector materialise. At the same time, cross-border inter-bank linkages are a transmission channel for financial market shocks that can raise the default probabilities of individual banks and systemic risk in the sector overall. The crisis revealed that liquidity risks for banks in Luxembourg can originate from their exposure to parent groups (IMF, 2011). In response, financial market supervisors adopted a number of micro- and macro-prudential measures to tackle underlying risks, notably a daily liquidity reporting requirement for credit institutions, reinforced liquidity oversight via onsite visits, macro-liquidity stress test on a regular basis, as well as measures to strengthen banks' capital base. 
In addition, investment funds and other financial intermediaries matter for the financial health of the banking system due to their significant financial linkage (Figure 3 above). In particular, investment funds provided some $15 \%$ of the banks' funding at the end of 2013 (Figure 3, panel A). While this funding remained stable during the crisis, showing resilience of the investment funds, there could be adverse spill-over effects from investment funds to banks if the former come under severe stress. Recent econometric research also points to the relevance for shock transmission of funding links from investment funds to banks (Jin and de Simone, 2014).

Dealing with the specificities of Luxembourg's financial market requires a comprehensive approach to risk assessment, efficient financial market supervision and prudent capital and liquidity provisioning of both banks and interlinked financial market actors. The move towards a Banking Union in the EU, including the Single Supervisory Mechanism (SSM) for large participating banks, the Single Resolution Mechanism (SRM), common rule books for bank supervision and resolution and stronger capital requirements implied by the capital requirements regulation and directive (CRR/CRD IV) can be beneficial for Luxembourg in that they help controlling counter-party risks stemming from the rest of the EU.

The SSM brought half of the 148 individual banks in Luxembourg, representing some $80 \%$ of the banks' assets, under the direct supervision of the ECB (European Central bank, 2014; IMF, 2014). However, effective risk control by the SSM requires efficient co-operation of the supervisory institutions at the EU level with the national competent authorities. The resource endowment of the Commission de Surveillance du Secteur Financier (CSSF), which is Luxembourg's supervisor for credit institutions, investment funds and other financial intermediaries, has been strengthened in recent years, bank stress testing techniques have been improved and investor protection was strengthened (IMF, 2014).

Risks to financial sector stability are assessed by the financial market regulator CSSF in cooperation with the Luxembourg Central Bank (BCL). The government plans to establish a national Systemic Risk Committee, involving all authorities that are relevant for macro-prudential policy: the CSSF, the BCL, the insurance regulator (CAA) and the ministry of finance. Identifying, assessing and monitoring risks to financial stability will be a key task of the Committee. For this cooperation to be successful it is important to elaborate the analytical framework that accounts for the financial linkages between the banks and the other relevant financial market actors, notably investment funds. The assessment framework should include indirect links via market prices and return correlations, as recent empirical research suggests (see Jin and de Simone, 2014).

The capital requirements of the banks in Luxembourg are driven by credit exposures (Table 1). By contrast, proprietary trading, which is often considered a major potential source for systemic risk (Blundell-Wignall and Atkinson, 2013; European Commission, 2014), plays only a minor role. The CSSF implemented a series of measures to strengthen banks' capital base. Some of these requirements exceed future Basle and EU minimum capital requirements (Box 2). Macro-prudential measures were also taken to address real estate market risks of the domestic banks. Regulators should maintain strong capital buffers to account for the various potential sources of risks in Luxembourg's financial sector. This should include maintaining high prudential capital provisions for mortgage loans. These loans continue to grow, although at lower rates, after a vigorous upswing over several years (Figure 15), and account for a high portion of the banks' credit. The EU CRRD IV allows bank supervisors to limit intra-group exposure. Depending on risk assessment, activation of this provision should be evoked as a preventive tool to minimise systemic risks. 
Table 1. Capital adequacy requirements for banks in Luxembourg

\begin{tabular}{lcc}
\hline Requirements (\% of total): & 2012 & 2013 \\
\hline to cover credit risk & 88.4 & 86.4 \\
to cover foreign exchange risk & 0.4 & 0.3 \\
to cover interest rate risk & 0.1 & 0.1 \\
to cover the risk in relation to equities & 0.0 & 0.0 \\
to cover the risk in relation to commodities & 0.0 & 0.0 \\
according to internal models & 0.2 & 0.2 \\
to cover settlement/delivery risk & 0.0 & 0.0 \\
to cover operational risk & 7.8 & 8.5 \\
Other capital adequacy requirements & 3.1 & 4.5 \\
Total capital adequacy requirements & 100 & 100 \\
\hline
\end{tabular}

Source: Commission de Surveillance du Secteur Financier, Luxembourg.

\section{Box 2. Macroprudential measures taken by the CSSF and the BCL}

Over the last four years of financial market tensions, the Commission de Surveillance du Secteur Financier, which shares financial market supervision with the Banque Centrale du Luxembourg and, more recently, with the European Central Bank, implemented a series of macro-prudential measures. These were designed to address exposure to developments on real estate markets and to strengthen the banks' capital base. The main measures were:

Measures addressing real estate exposures:

- Effective since July 2013 , the risk-weight requirement for new mortgage loans that exceed a loan-to-value (LTV) ratio of $80 \%$ was tightened. These exposures can no longer receive the preferential $35 \%$ risk weight.

- Various qualitative requirements include bank internal limits to exposures to real estate developers, fixation of a repayment date of the credit exposure and the prohibition of rollover of interest payments at maturity.

- Until beginning of 2014 , a capital surcharge of $2 \%$ was applied to the domestically-oriented banks issuing mortgage credits. The $2 \%$ surcharge was the result of a stress testing exercise conducted by CSSF, showing that a severe downturn in the Luxembourg real estate market could potentially result in a capital depletion of up to $2 \%$. With the European Union's CRD IV package, as per beginning of 2014, this was replaced by the capital conservation buffer of $2.5 \%$ for all banks.

Capital strengthening measures:

- In 2011, the European Banking Authority issued its recommendation on the creation and supervisory oversight of temporary capital buffers to restore market confidence (EBA/REC/2011/1) to build a temporary capital buffer to reach a 9\% Core Tier 1 ratio by 30 June 2012. The EBA recommendation directly applied to only one (domestic) bank in Luxembourg. CSSF chose to apply the measure to all banks in Luxembourg.

- With the entry into force of the Basel III rules, CSSF has opted for a CET1 capital requirement of $4.5 \%$ instead of $4 \%$ (CRR, Article 465).

- There will be no phasing in of unrealised gains in the capital ratio until end of 2017 (CRR Article 467).

- An additional capital conservation buffer of $2.5 \%$ for all banks has been introduced as per beginning of 2014 , as mentioned above (CRDIV, Article 129).

- By the end of 2014, a new CSSF Regulation will enter into force prohibiting dividend payments based on unrealized gains.

- Unrealised gains for investment properties must not be reflected in the capital ratio.

Other macro prudential measures:

- CSSF and BCL have issued directives via common circulars to mitigate risks associated with bank lending in foreign currency and asset encumbrance.

- According to part four of the CRR, Luxembourg banks can exempt exposures to group-related entities from the large exposure limit. Per Regulation 14-01 (Article 20), the CSSF has been empowered to limit or suspend the aforementioned exemption in case the waiver would lead to material risks for the solvency or liquidity position of the Luxembourg bank. 
Figure 15. Credit granted by credit institutions for real estate located in Luxembourg

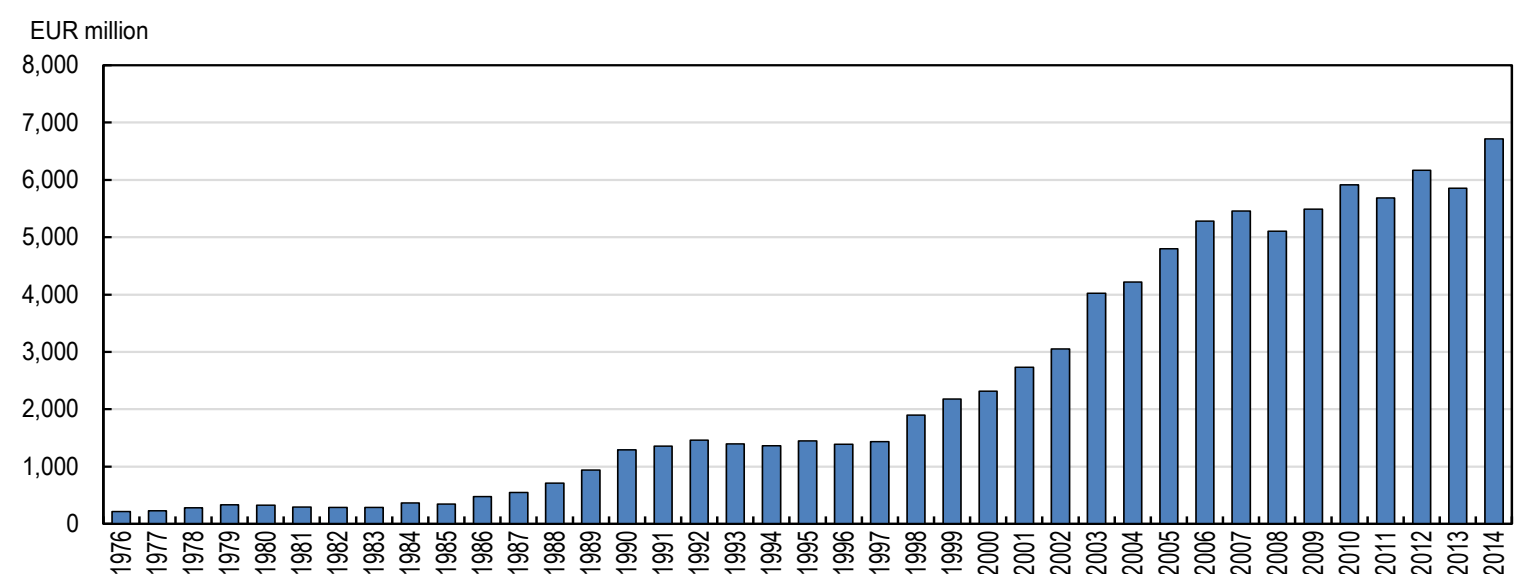

Source: BCL.

As of 2013, 74\% of Luxembourg's affiliates of international banks were subsidiaries, the rest being branches (Figure 16). For the subsidiaries, claims on the resources of Luxembourg's deposit insurance system and demands to finance resolution can arise, even if the subsidiaries are well capitalised. Branches fall under the policies of the mother country. Adaptation of Luxembourg's deposit insurance scheme is under way to meet future pre-funding requirements of the EU Deposit Guarantee Schemes Directive. Moreover, it is welcome that the CSSF has strengthened the criteria to be complied with when engaging into large intragroup transactions. Ownership links between banks across different legal entities and borders can provide a certain degree of risk sharing. Within the EU, Supervisory Colleges, involving the national supervisory authorities, serve to exchange information and coordinate key supervisory tasks across borders. In the European banking union, banking groups are supervised by the SSM via joint supervisory teams, and the SRM is responsible for resolution planning and resolution of cross-border European banking groups. However, financial linkages across borders can complicate bank resolution in bad times in particular for bank groups with dependencies located outside the European Banking Union. Thus, the authorities should ensure that resolution plans continue to be developed and resolvability assessments undertaken so that important banks could be resolved effectively across borders if necessary. Credible bailin and resolution provisions contribute to better resource allocation and can thus benefit Luxembourg's position as a major financial centre.

Figure 16 Branches and subsidiaries in Luxembourg by foreign credit institutes

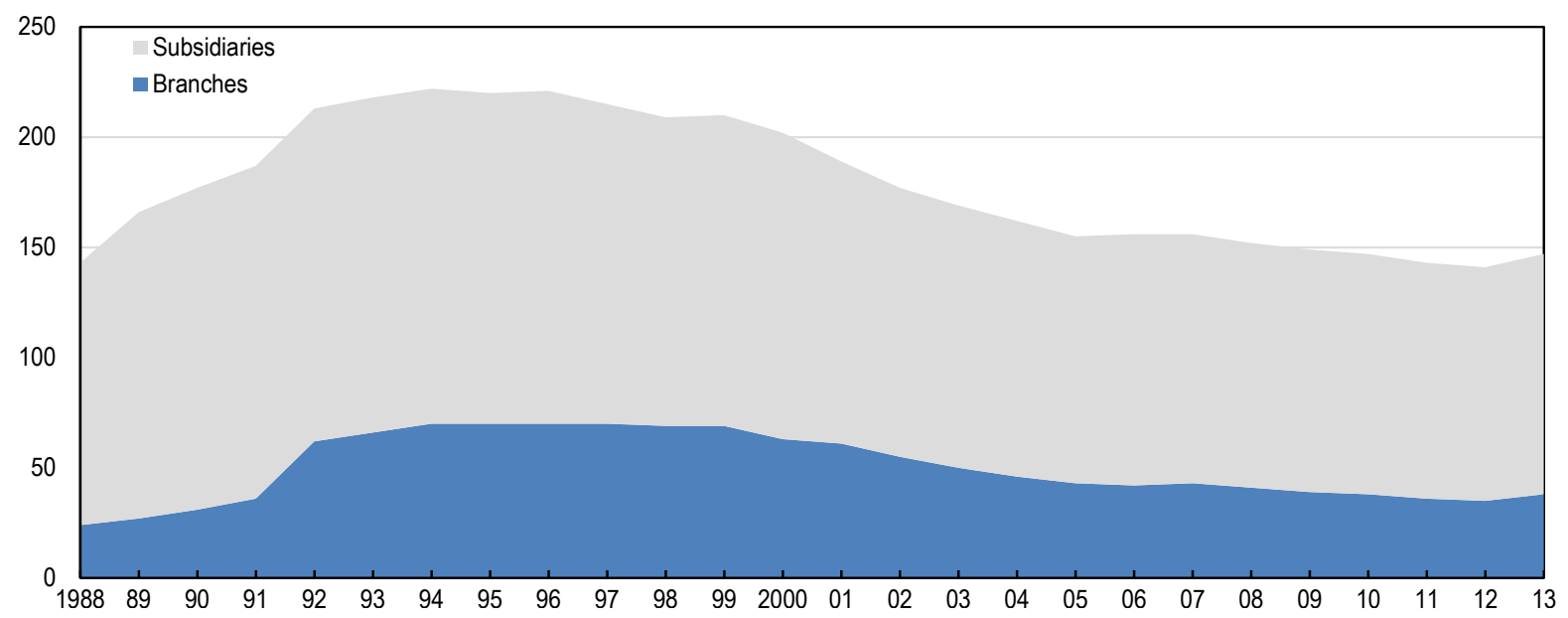

Source: Commission de Surveillance du Secteur Financier, Luxembourg. 


\section{ANNEX \\ MEASURING OUTPUT AND PRODUCTIVITY IN THE FINANCIAL SECTOR ${ }^{2}$}

The output of banks at current prices is measured directly in the case of explicitly-priced services (such as fees for current accounts or fees for management of investment funds). This is augmented by implicitly-priced services, the so-called financial intermediation services indirectly measured (FISIM), provided in relation to loans and deposits, which are more difficult to measure.

FISIM on loans is computed as $\left(r_{L}-r\right) Y_{L}$, where $r_{L}$ is the interest rate on loans, $r$ is a reference rate (measured as a rate between bank interest rates on deposits and loans) and $\mathrm{Y}_{\mathrm{L}}$ is the nominal amount of outstanding loans. Banking services to borrowers are thus measured as a margin between the interest paid by borrowers and the (risk free) interest rate. The reference rate may be calculated as an average of the rates on loans and deposits. An alternative is to use, for example, the rate of inter-bank loans. Similarly, depositor services are measured as $\left(r-r_{D}\right) Y_{D}$, where $r_{D}$ is the interest paid to depositors and $Y_{D}$ is the value of deposits. Depositors will normally be paid a rate that is below the reference rate and the difference corresponds to the services that a bank provides to depositors. The total value of banking services at current prices is then (approximately) given as $\left(r_{L}-r\right) Y_{L}+\left(r-r_{D}\right) Y_{D}+S$, where $S$ stands for the value of explicitly-priced banking services.

To translate this into volumes, the explicitly-priced services $\mathrm{S}$ are typically deflated using a suitable price index. In the case of margin-type explicit service charges, e.g. for managing investment portfolios or sales and purchases of securities or currencies, an implicit price index is calculated that reflects both the changes in the percentage charged and the changes in the prices of the underlying assets (stocks or flows) to which this percentage rate is applied. If, for example, the stock market goes up and fund managers' fees are rising proportionally, the implicit price index will thus also rise, and applying it to the fees means that the volume service by fund managers remains relatively stable. The same logic, with inverted signs, applies in a period of downturn. As a consequence, constant price fees would be relatively unaffected by stock market movements. In the case of currencies or money funds, a volume indicator could be based on the amounts transacted or managed, deflated by a price index that measures the change in the underlying purchasing power of money.

To obtain a measure of constant-price FISIM, the values of the interest margins $\left(\mathrm{r}^{\mathrm{t}-1}-\mathrm{r}_{\mathrm{D}}{ }^{\mathrm{t}-1}\right) \mathrm{Y}_{\mathrm{D}}^{\mathrm{t}-1}$ and $\left(\mathrm{r}_{\mathrm{L}}^{\mathrm{t}-1}-\mathrm{r}^{\mathrm{t}-1}\right) \mathrm{Y}_{\mathrm{L}}^{\mathrm{t}-1}$ of a base year $\mathrm{t}-1$ are extrapolated by applying a volume index of the intermediated funds. The volume indexes $\mathrm{V}_{\mathrm{D}}{ }^{t}$ and $\mathrm{V}_{\mathrm{L}}{ }^{t}$ reflect the evolution of the value of the stock of deposits and loans respectively, deflated by the price index of domestic demand, $\mathrm{P}^{\mathrm{t}} / \mathrm{P}^{\mathrm{t}-1}$, so that $\mathrm{V}_{\mathrm{D}}{ }^{\mathrm{t}}=\left[\mathrm{Y}_{\mathrm{D}}{ }^{\mathrm{t}} / \mathrm{Y}_{\mathrm{D}}^{\mathrm{t}-1}\right] /\left[\mathrm{P}^{\mathrm{t}} / \mathrm{P}^{\mathrm{t}-1}\right]$ and $\mathrm{V}_{\mathrm{L}}^{\mathrm{t}}=\left[\mathrm{Y}_{\mathrm{L}}^{\mathrm{t}} / \mathrm{Y}_{\mathrm{L}}^{\mathrm{t}-1}\right]\left[\mathrm{P}^{\mathrm{t}} / \mathrm{P}^{\mathrm{t}-1}\right]$.

So, constant price FISIM for year $t$ is then $\quad\left[\left(r_{L}{ }^{t-1}-r^{t-1}\right) Y_{L}{ }^{t} V_{L}{ }^{t}+\left(r^{t-1}-r_{D}{ }^{t-1}\right) Y_{D}{ }^{t} V_{D}{ }^{t}\right]$

$$
=\left[\left(\mathrm{r}_{\mathrm{L}}^{\mathrm{t}-1}-\mathrm{r}^{\mathrm{t}-1}\right) \mathrm{Y}_{\mathrm{L}}^{\mathrm{t}}+\left(\mathrm{r}^{\mathrm{t}-1}-\mathrm{r}_{\mathrm{D}}^{\mathrm{t}-1}\right) \mathrm{Y}_{\mathrm{D}}^{\mathrm{t}}\right] /\left[\mathrm{P}^{\mathrm{t}} / \mathrm{P}^{\mathrm{t}-1}\right]
$$

FISIM is allocated to depositors and to borrowers, where the latter typically are corporations or households with a mortgage loan. As a result, most of $\left(\mathrm{r}_{\mathrm{L}}^{\mathrm{t}-1}-\mathrm{r}^{\mathrm{t}-1}\right) \mathrm{Y}_{\mathrm{L}}^{\mathrm{t}-1} \mathrm{~V}_{\mathrm{L}}{ }^{\mathrm{t}}$ is a real intermediate input that does not affect GDP unless it is exported. FISIM on consumer credits will normally feed into final consumption expenditure. On the other hand, depositors are typically households, so GDP volumes would be more affected by $\left(\mathrm{r}^{\mathrm{t}-1}-\mathrm{r}_{\mathrm{D}}^{\mathrm{t}-1}\right) \mathrm{Y}_{\mathrm{D}}^{\mathrm{t}-1} \mathrm{~V}_{\mathrm{D}}^{\mathrm{t}}$.

\footnotetext{
${ }^{2}$ This annex has been written by Peter van de Veen of the OECD's Statistics Directorate.
} 
Because of the above methods for calculating direct bank charges and FISIM in constant prices, the growing share in GDP of value added generated by financial services can be mainly attributed to increasing relative (implicit) prices, not to the volume changes in financial services which contribute to economic growth. Furthermore, it is not immediately clear how the economic and financial crisis shows up in the measure of FISIM-output unless the stock of deposits and bonds is affected in which case $\mathrm{V}^{\mathrm{t}}$ would grow more slowly than otherwise. Because the interest margins are kept fixed between adjacent years in the volume calculations, a narrowing or widening of interest margins would not show up in year-to-year volume growth rates. Also, FISIM is measured only on loans and deposits and not on any other assets or liabilities on the balance sheets, let alone any off-balance sheet items.

Looking at developments in (labour) productivity, these will mainly reflect changes in the volume of intermediated loans and deposits (FISIM), the changes in the underlying volumes of traded financial instruments or stocks of investment portfolios managed (direct charges), etc. per unit of labour input. Lower or higher margins would typically not feed into changes in productivity.

The increasing share of financial services in GDP has generated a debate on the measurement of financial services, on whether or not the value of bank output is exaggerated. The issue is the inclusion of risk elements in the calculation of FISIM, of which the most prominent examples are maturity risk and credit default risk. Recent revisions of the System of National Accounts (SNA, 2008) and the European System of Accounts (ESA 2010), agreed to include maturity risk, as the management of differences in maturities of loans and deposits is normal business of banks. On credit default risks some countries prefer to exclude (a smoothed measure of) loan charge-offs from the FISIM - e.g. the United States plans to exclude the latter costs from FISIM, while European countries will not. In the case of the economic and financial crisis, showing quickly increasing charge-offs, the exclusion will most certainly affect the value of financial services negatively. However, generally speaking, it will not affect the measurement of FISIM at constant prices and thus the volume changes in financial services. 


\section{BIBLIOGRAPHY}

Arcand, J.-L., E. Berkes, and U. Panizza (2012), Too Much Finance?, IMF Working Paper 12/161.

Beck, R., G. Georgiadis and R. Straub (2014), “The Finance and Growth Nexus Revisited”, Economics Letters, Vol. 124, Issue 3.

Blundell-Wignall, A., P. Atkinson and C. Roulet (2013), "Bank Business Models and the Basel System: Complexity and Interconnectedness", OECD Journal: Financial Market Trends, Vol. 2013(2), OECD Publishing, Paris, http://dx.doi.org/10.1787/fmt-2013-5jzb2rhkd65b.

Cecchetti, S. G. and E. Kharroubi (2012), "Reassessing the Impact of Finance on Growth", BIS Working Papers, No. 381.

Cournède, B., O. Denk and P. Hoeller (2015), "Finance and Inclusive Growth”, OECD Economic Policy Papers, No. 14, OECD Publishing, Paris.

Cournède, B. and O. Denk (2015), "Finance and Economic Growth in OECD and G20 Countries", OECD Economics Department Working Papers, No. 1223, OECD Publishing, Paris.

CSSF (2011), Commission de Surveillance du Secteur Financier, Raport d'activité 2010.

European Commission (2014), Proposal for a regulation of the European Parliament and of the Council on structural measures improving the resilience of EU credit institutions, COM/2014/043 final 2014/0020 (COD).

European Central Bank (2014a), Aggregate Report on the Comprehensive Assesment. https://www.bankingsupervision.europa.eu/ecb/pub/pdf/aggregatereportonthecomprehensiveassessm ent201410.en.pdf

European Central Bank (2014b), The list of significant supervised entities and the list of less significant institutions.https://www.ecb.europa.eu/pub/pdf/other/ssmlistofsupervisedentities1409en.pdf?59d76de0c5663687f594250ebf228c6b

European Parliament (2014), Single Supervisory Mechanism - Size of directly supervised banks (list at entity level).

http://www.europarl.europa.eu/document/activities/cont/201409/20140930ATT90266/20140930AT T90266EN.pdf

European Systemic Risk Board (2014), “Is Europe Overbanked?", Reports of the Advisory Scientific Committee, No. 4. https://www.esrb.europa.eu/pub/pdf/asc/Reports_ASC_4_1406.pdf

Guarda, P. and A. Rouabah (2011), Sectoral Output Growth and Dynamic Conditional Correlations. Paper presented at the Conference "Banking, Productivity \& Growth", Bank of Luxembourg, 28-29 March 2011. 
IMF (2011), Luxembourg: Financial System Stability Assessment - Update, IMF Country Report No. $11 / 148$.

IMF (2014), Luxembourg - Selected Issues, IMF Country Report No. 14/119.

Jin, X. and F de Simone (2014), Tracking changes in the intensity of Financial Sectors' Systemic Risk. Forthcoming.

Law, S. H. and N. Singh (2014), “Does Too Much Finance Harm Economic Growth?”, Journal of Banking \& Finance, Vol. 41.

OECD (2010), OECD Economic Survey Luxembourg.

OECD (2012), OECD Economic Survey Luxembourg.

OECD (2013), Interconnected Economies: Benefiting from Global Value Chains, OECD Publishing, Paris. DOI: http://dx.doi.org/10.1787/9789264189560-en

OECD (2014a), "Finance and inclusive growth", ECO/CPE/WP1(2014)16.

OECD (2014b), "The Role of the Financial Sector for Economic Growth in OECD and G20 Countries", $\mathrm{ECO} / \mathrm{CPE} / \mathrm{WP} 1(2014) 6$.

Schich, S. and L. Lindh (2012), Implicit Guarantees for Bank Debt: Where Do We Stand? Financial Market Trends, Volume 2012, Issue 1.

STATEC (2008), La situation économique au Luxembourg, Note de conjuncture 3/2007. Évolution récente et perspectives.

Wintersteller (2013), Luxembourg's financial centre and its deposits, European Commission, ECFIN Country Focus, Volume 10, Issue 9. 


\section{WORKING PAPERS}

The full series of Economics Department Working Papers can be consulted at www.oecd.org/eco/workingpapers

1238. Spillovers from the global productivity frontier and public policy: industry level evidence (June 2015) by Alessandro Saia, Dan Andrews and Silvia Albrizio

1237. The stabilisation properties of immovable property taxation: Evidence from OECD countries (May 2015) by Hansjörg Blöchliger, Balázs Égert, Bastien Alvarez and Aleksandra Paciorek

1236. Making the most of natural resources in Indonesia

(May 2015) by Richard Dutu

1235. Reforming the pension system to increase coverage and equity in Colombia.

(May 2015) by Christine de la Maisonneuve

1234. Making Colombia's tax policy more efficient, fair and green

(May 2015) by Christian Daude, Sarah Perret and Bert Brys

1233. Skills and labour market performance in Sweden

(May 2015) by Margherita Bussi and Jon Kristian Pareliussen

1232. Skills and inclusive growth in Sweden

(May 2015) by Jon Kristian Pareliussen, Margherita Bussi, Christophe André and Vincent Koen

1231. Incorporating anchored inflation expectations in the Phillips Curve and in the derivation of OECD measures of equilibrium unemployment

(May 2015) by Elena Rusticelli, David Turner and Maria Chiara Cavalleri

1230. Macroeconomic uncertainties, prudent debt targets and fiscal rules,

(July 2015) by Falilou Fall and Jean-Marc Fournier

1229. Limits to government debt sustainability

(July 2015) by Jean-Marc Fournier and Falilou Fall

1228. Government debt indicators: understanding the data

(July 2015) by Debbie Bloch and Falilou Fall

1227. The costs of flexibility-enhancing structural reforms: a literature review

(July 2015) by Tito Boeri, Pierre Cahuc and André Zylberberg

1226. Household finance and income inequality in the euro area

(June 2015) by Oliver Denk and Alexandre Cazenave-Lacroutz

1225. Financial sector pay and labour income inequality: evidence from Europe

(June 2015) by Oliver Denk

1224. Finance and income inequality in OECD countries

(June 2015) by Oliver Denk and Boris Cournède 
1223. Finance and economic growth in OECD and G20 countries

(June 2015) by Boris Cournède and Oliver Denk

1222. What impedes household investment in energy efficiency and renewable energy?

(May 2015) by Nadia Ameli and Nicola Brandt

1221. Recent trends in productivity in China - shift-share analysis of labour productivity growth and the evolution of the productivity gap

(May 2015) by Margit Molnar and Thomas Chalaux

1220. Assessing China's skills gap and inequalities in education

(May 2015) by Margit Molnar, Boqing Wang and Ruidong Gao

1219. Providing the right skills to all in China - from "made in China" to "created in China"

(May 2015) by Margit Molnar and Vincent Koen

1218. Agricultural reforms and bridging the gap for rural China

(May 2015) by Ben Westmore

1217. A snapshot of China's service sector

(May 2015) by Margit Molnar and Wei Wang

1216. Does the post-crisis weakness of global trade solely reflect weak demand?

(May 2015) by Patrice Ollivaud and Cyrille Schwellnus

1215. Estonia: raising productivity and benefitting more from openness

(May 2015) by Andreas Kappeler

1214. Estonia: making the most of human capital

(May 2015) by Andrés Fuentes Hutfilter

1213. The Czech labour market: documenting structural change and remaining challenges

(May 2015) by Sónia Araújo and Petr Malecek

1212. Reforming the Slovak public sector

(April 2015) by Lilas Demmou and Robert Price

1211. Spurring growth in lagging regions in the Slovak Republic

(April 2015) by Lilas Demmou, Gabriel Machlica, Martin Haluš and Robert Menkyna

1210. Skill mismatch and public policy in OECD countries

(April 2015) by Müge Adalet McGowan and Dan Andrews

1209. Labour market mismatch and labour productivity: evidence from PIAAC data

(April 2015) by Müge Adalet McGowan and Dan Andrews

1208. Maintaining an efficient and equitable housing market in Belgium

(April 2015) by Sanne Zwart 